medRxiv preprint doi: https://doi.org/10.1101/2020.07.28.20163873; this version posted July 30, 2020. The copyright holder for this preprint

(which was not certified by peer review) is the author/funder, who has granted medRxiv a license to display the preprint in perpetuity.

It is made available under a CC-BY-NC-ND 4.0 International license .

\title{
Determining the period of communicability of SARS-CoV-2: A rapid review of the literature
}

\section{Authors}

Mina Park ${ }^{1}$, Colleen Pawliuk ${ }^{2}$, Tribesty Nguyen ${ }^{3}$, Amanda Griffitt $^{2}$, Linda Dix-Cooper ${ }^{1}$, Nadia Fourik $^{1}$, Martin Dawes ${ }^{3}$

\section{Author Affiliations}

1. Vancouver Coastal Health, Vancouver, British Columbia, Canada

2. School of Information, University of British Columbia, Vancouver, British Columbia, Canada

3. Faculty of Medicine, University of British Columbia, Vancouver, British Columbia, Canada

*Corresponding Author: Mina Park, mina.park@vch.ca

\section{Acknowledgements}

We would like to thank Kelsey Furk and John Harding for their contributions to the development and design of this study.

\begin{abstract}
Introduction: How long individuals may transmit virus after infection with severe acute respiratory syndrome coronavirus 2 (SARS-CoV-2) is unclear. Understanding the communicability period of SARSCoV-2 is important to inform the period of isolation required to prevent nosocomial and community spread. The objective of this study was to identify the reported communicable period of SARS-CoV-2, based on a rapid review of existing literature.
\end{abstract}

Methods: Studies reporting empirical data on the period of communicability of SARS-CoV-2 through investigations of duration of communicability based on in-person contact ("contact transmission"), isolation and culture of virus ("viral isolation"), and viral shedding by detection of nucleic acids by RTPCR ("viral shedding") were identified through searches of peer-reviewed and pre-print health sciences literature databases (Ovid MEDLINE, Embase, Google Scholar, medRxiv and arXiv) and the grey literature. Articles were screened for relevance, then data were extracted, analyzed, and synthesized.

Results: Out of the 165 studies included for qualitative analysis, one study investigated contact transmission, three investigated viral isolation, 144 investigated viral shedding, and 17 studies focused on both viral shedding and viral isolation. The median length of time until viral clearance across all viral isolation studies was nine days; however, the maximum identified duration was 32 days. Studies with data on both viral isolation and viral shedding showed a prolonged maximum time until viral clearance for viral shedding ( 9 days vs 24 days).

Discussion: Findings from this review support a minimum 10-day period of isolation; however, additional observation should be considered for individuals being released into high-risk settings. 
medRxiv preprint doi: https://doi.org/10.1101/2020.07.28.20163873; this version posted July 30, 2020. The copyright holder for this preprint (which was not certified by peer review) is the author/funder, who has granted medRxiv a license to display the preprint in perpetuity. It is made available under a CC-BY-NC-ND 4.0 International license .

\section{Introduction}

Understanding how long individuals may continue to transmit virus after infection with severe acute respiratory syndrome coronavirus 2 (SARS-CoV-2) is important to inform policies on the period of isolation required to prevent nosocomial and community spread. There are two main strategies on discontinuation of isolation for cases [1-3]. The first, a test-based strategy, relies on resolution of symptoms accompanied by single or consecutive negative results from reverse transcriptase polymerase chain reaction (RT-PCR)-based tests, taken from respiratory samples. The second approach requires adherence to a set period of isolation (typically, 10 - 14 days from symptom onset or from the first positive test) in addition to resolution of symptoms.

While a test-based strategy may be preferred as providing an indication of viral clearance, this approach has important limitations. Viral shedding, as detected by the presence of viral nucleic acid by RT-PCR, does not equate to infectiousness as nucleic acid tests do not differentiate between live (or viable) and non-infective virus [4]. Moreover, the performance of SARS-CoV-2 PCR-based tests is inconsistent, with inconclusive test results being reported based on variations in individual viral shedding patterns.

Anecdotal reports have emerged of individuals remaining in prolonged isolation due to continuous positive RT-PCR results, long after resolution of symptoms, with unintended adverse consequences [5]. Due to these issues, a fixed quarantine period and symptom resolution continues to be an important alternative or complimentary strategy.

To inform the fixed quarantine period strategy, it is important to understand as much as possible about the infectious period (called the communicability period in the rest of this paper). As such, the goal of this study was to identify reported communicable periods of SARS-CoV-2, based on a comprehensive review of existing literature. From an initial investigation into this topic, previous reviews were identified, a rapid scoping review and a systematic review, that investigated the potential duration of communicability $[6,7]$. However, a preliminary assessment of results from an independent search identified a number of additional studies that were not captured in either of these reviews. As these subsequent studies may alter the previous review findings, this review was conducted to include a greater number of studies, and more recent ones, than previous reports. Moreover, the scope of this review was specifically intended to include studies reporting empirical data on the period of communicability of SARS-CoV-2 through investigations of duration of communicability based on inperson contact ("contact transmission"), isolation and culture of virus ("viral isolation"), and viral shedding by detection of nucleic acids by RT-PCR ("viral shedding").

\section{Methods}

We conducted a rapid review of the literature using the methods outlined in the National Collaborating Centre for Methods and Tools Guidebook [8]. We used the PRISMA guidelines to report our rapid review [9]. We did not publish or pre-register a protocol for our review. From the available data communicability duration (maximums, medians or means values) was retrieved or calculated.

Search strategy: We searched peer-reviewed and pre-print health sciences literature databases (Ovid MEDLINE, Embase, Google Scholar, medRxiv and arXiv) and the grey literature for reports or guidelines on discontinuation of isolation for SARS-CoV-2 from international and national public health organizations (World Health Organization, European Centre for Disease Prevention and Control, US Centre for Disease Control websites). Our review included two search strategies: 1) terms for 'SARS-CoV- 
medRxiv preprint doi: https://doi.org/10.1101/2020.07.28.20163873; this version posted July 30, 2020. The copyright holder for this preprint (which was not certified by peer review) is the author/funder, who has granted medRxiv a license to display the preprint in perpetuity. It is made available under a CC-BY-NC-ND 4.0 International license .

2 ' and 'viral clearance/shedding,' on May 23, 2020; and 2) terms for 'SARS-CoV-2' and 'viral isolation/culture,' on July 1, 2020. We updated the second search to July 1, 2020 because there was a paucity of studies with data from viral isolation/cultures in the previous iteration of the search and identifying the duration of viable virus through studies on viral isolation was identified as key to understanding the potential infectious period of SARS-CoV-2. All databases were searched from inception and searches were limited to English. Detailed information on search strategies undertaken in each database can be found in Supplementary Materials. The references of select high-impact articles, reports from reputable sources, and existing reviews on the topic were reviewed and missing studies were added to search results. Any missing studies identified through other sources or contacts were manually added.

Inclusion criteria: Studies presenting primary empirical data on duration of possible communicability of SARS-CoV-2 in human populations and reported in English were included. Articles that did not report data on duration of potential communicability, either in the text, figures, or tables were excluded. Studies reporting solely on pre-symptomatic durations, incubation periods, serial intervals, or on results based on statistical modelling were excluded. Studies that used data from other investigations were excluded; any reviews were identified and their references were reviewed to add relevant primary studies. When duplicate study reports were identified (i.e. a pre-print and a peer-reviewed journal article), the most recent version was included.

Screening process: Titles and abstracts were screened for relevance independently and in duplicate by two reviewers. Full-text review was conducted by two reviewers independently and in duplicate for articles where relevance was not readily determined from title and abstracts, and any conflicts were resolved through consensus by the two reviewers.

Data extraction process: A draft data extraction form was developed and trialled across multiple reviewers to develop the final version. Extracted data fields included study characteristics (first author, publication status, study type, sample size), study population characteristics (age, hospitalization, disease severity), method of determining infectious period (contact transmission, viral shedding, viral isolation), type of specimen(s) collected (respiratory, other), reported durations (minimum, mean, median, maximum), whether cases without symptoms (either asymptomatic or pre-symptomatic) were reported, whether the study focused solely on duration of communicability during the convalescent phase, how measurement of duration start and end was defined, and study quality. All extracted data was reviewed by a second reviewer.

Definitions: Sample size was defined as the total number of participants for which data on communicability period was assessed. Disease severity associated with SARS-CoV-2 infection was classified according to the following definitions: mild referred to study populations reporting no symptoms or non-serious symptoms that did not require healthcare intervention, moderate severity included participants that required acute care and/or intervention, and severe disease referred to cases that required admission to the intensive care unit, critical intervention, and/or resulted in death. Studies that included participants with mild, moderate, and severe cases were classified as "mixed"; otherwise, if they included cases that were mild/moderate or moderate/severe, they were identified as belonging in the category indicating a higher level of severity. Hospitalization status was determined based on whether the study described if participants had been hospitalized during the study period. Notably, in some jurisdictions, admission to hospital appeared to be part of routine isolation policies and so this description alone was not taken as an indicator of disease severity. Studies with children were identified if they included participants aged individuals 19 years or younger. Respiratory samples included those

Page 3 of 34 
medRxiv preprint doi: https://doi.org/10.1101/2020.07.28.20163873; this version posted July 30, 2020. The copyright holder for this preprint (which was not certified by peer review) is the author/funder, who has granted medRxiv a license to display the preprint in perpetuity. It is made available under a CC-BY-NC-ND 4.0 International license .

taken from the upper (including those identified as naso/oro-pharyngeal, nasal, throat, or saliva swabs) or lower respiratory tract (from sputum or bronchial lavage specimens).

Assessment of study quality: An adaptation of the Mixed Methods Appraisal Tool was used to assess study quality [10]. Questions were concerned with the following: 1) the study had clear research questions or objectives; 2 ) the collected data allowed the study to address the stated research question; 3) the research question was aimed at understanding duration of communicability; 4) there was a complete follow-up period defined to measure duration of communicability; and 5) there was clarity in how measurements were made in terms of: a) clear delineation of when measurement of communicability period started; b) sample types collected \& frequency of sample collection was outlined; c) how long patients were followed (until viral clearance, study end, hospital discharge, death); and d) method of assessment of communicability was clearly explained. The results of the study quality assessment are included in Table 1. Due to the emerging nature of this topic and paucity of evidence, we did not exclude studies from our synthesis or analysis based on study quality.

Analysis: All data processing and analysis was conducted using the statistical programming language $R$ (version 4.0.0) [11]. For studies where more than one value was reported for duration (ie, when there was data reported for multiple sample types, or results were presented in a stratified manner), the values corresponding to the higher duration of communicability were included for analysis. As analyses were generally aimed at identifying the maximum reported period of communicability, these values were pulled from each study and summarized. Raw data are available in Supplementary Materials.

\section{Results}

\section{Results of literature search}

From database manual searches, 2,174 records were retrieved, and 60 additional studies were identified from reference chaining and manually (2,234 total), of which 1,458 remained after removing duplicate records. Of these, 1,234 were excluded in screening and 59 in full-text review as they did not report data on duration of infectiousness, used secondary data from the literature, full-text was not accessible, or they were duplicate reports of the same study. 165 studies were included in the final synthesis. See Figure 1 for the PRISMA flowchart diagram that illustrates the study selection process.

\section{Study characteristics}

Information on study characteristics is presented in Table 1, overall and broken down by method of assessment. Out of 165 total included studies, one study investigated contact transmission, three investigated viral isolation, 144 investigated viral shedding, and 17 studies focused on both viral shedding and viral isolation. The study sample sizes of included studies ranged from 1 to 2861, with a mean of 71.98 (SD 245.78) and a median of 16 (IQR 67.00). Studies that investigated both viral isolation and shedding had a mean sample size of 89.24 (SD 252.91) and a median of 9 (IQR 65.25) (range 11061). The mean and median sample size in viral isolation studies was 72.33 and 65 respectively (SD 53.40; IQR, 53.00; range 23-129). In viral shedding studies, the mean sample size was 50.56 (SD 85.78) and the median was 15 (IQR 65.25) (range 1-584). The majority of studies consisted of case series ( $n=104,63.03 \%)$, while $37(22.42 \%)$ were case reports, cohort ( $n=15,9.09 \%)$, cross-sectional $(n=4$, $2.42 \%)$, clinical trial $(n=3,1.82 \%)$ and case control studies $(n=2,1.21 \%)$ (Table 1$)$.

The majority of studies were conducted in Asia ( $n=135,81.81 \%)$, with 17 studies conducted in Europe (10.30\%), 10 in North America (6.06\%), 2 in the Middle East (1.21\%), and 1 in Australia (0.61\%) (Table 1). 
medRxiv preprint doi: https://doi.org/10.1101/2020.07.28.20163873; this version posted July 30, 2020. The copyright holder for this preprint (which was not certified by peer review) is the author/funder, who has granted medRxiv a license to display the preprint in perpetuity. It is made available under a CC-BY-NC-ND 4.0 International license .

Unique countries that were represented were: Australia ( $n=1)$, Canada ( $n=3)$, China ( $n=106)$, Finland $(n=1)$, France $(n=5)$, Germany ( $n=3)$, Hong Kong $(n=4)$, India $(n=1)$, Italy $(n=4)$, Japan $(n=2)$, Lebanon $(n=1)$, Saudi Arabia $(n=2)$, Scotland $(n=1)$, Singapore $(n=4)$, South Korea $(n=7)$, Spain $(n=1)$, Taiwan $(n=4)$, Thailand ( $n=1)$, The Netherlands ( $n=1)$, United Arab Emirates ( $n=1)$, United States $(n=7)$, and Vietnam $(n=4)$.

Study populations had mixed disease severity (i.e., included mild, moderate and severe disease) in 47 studies (28.48\%). Thirty-eight studies $(23.03 \%)$ had participants with only mild symptoms, while 35 (21.21\%) studies had moderate symptoms, and 13 (7.88\%) with severe disease. Thirty-two studies (19.39\%) did not provide information on disease severity. The majority of studies included only hospitalized patients ( $n=140,84.85 \%$ ). Fifteen studies $(9.09 \%$ ) included a mixed population of hospitalized and non-hospitalized patients, four included only non-hospitalized patients (2.42\%) and for six studies (3.63\%), hospitalization status of study participants was unclear. Most of the studies included only adults ( $n=118,71.52 \%)$, while 18 studies (10.91\%) focused solely on pediatric populations, and 29 studies (17.58\%) had a mixed population of children and adults.

The starting points for measuring duration were symptom onset $(n=89 ; 53.94 \%)$, hospital admission $(n=37 ; 22.42 \%)$, when the patient first tested positive for SARS-CoV-2 ( $n=11 ; 6.67 \%)$, or other ( $n=28$, $16.97 \%)$. Overall across studies, the end points of duration were the date of a single or consecutive negative RT-PCR test ( $n=114 ; 69.09 \%)$, discharge/death ( $n=9 ; 5.45 \%$ ) last positive test ( $n=6 ; 3.64 \%)$, or other $(n=36,21.82 \%)$. The end point for measuring duration of viral isolation was the last reported day that virus was able to be successfully isolated and cultured (captured under "other"). For the purposes of this review, we will refer to the start of measurement of duration as 'symptom onset' and measurement end as 'viral clearance.'

The majority of included studies collected data from respiratory samples, with or without another type of sample ( $n=161,97.57 \%)$. Three studies (1.82\%) investigated non-respiratory samples only, and 1 study $(0.61 \%)$ collected no samples as it used contact transmission to determine duration of communicability.

Seventy-three studies (44.24\%) included asymptomatic or pre-symptomatic positive cases. Of the studies assessing viral isolation, four studies (25.00\%) also isolated and cultured virus from patients who were asymptomatic, or during their pre-symptomatic or convalescent disease period [12-15]. Two studies with data on viral isolation focused on isolating virus from non-respiratory samples, one in urine that was isolated on day 12 [16] and one in fecal matter that was isolated on day 19 after symptom onset [17]. Seven studies (4.24\%) focused solely on convalescent patients who re-tested positive via RTPCR after discharge from hospital/clearance of isolation, but only 1 of these studies attempted viral isolation, which was unsuccessful [18].

At the time of writing, 26 (15.76\%) of the studies included in this review are pre-prints and thus have not undergone peer-review. Many of the remaining studies published in peer-review journals are letters to the editor or other short communications that do not fully report their methods. There was variation in study quality in both pre-prints and studies published in peer-reviewed journals. Forty-three studies (26.06\%) had one study quality concern, 52 studies (31.51\%) had two study quality concerns, 32 studies (19.39\%) had three study quality concerns, six studies (3.63\%) had four study quality concerns and two studies (1.21\%) had all five study quality concerns. Only 30 studies (18.18\%) did not have a single quality concern based on our assessed criteria. 
medRxiv preprint doi: https://doi.org/10.1101/2020.07.28.20163873; this version posted July 30, 2020. The copyright holder for this preprint (which was not certified by peer review) is the author/funder, who has granted medRxiv a license to display the preprint in perpetuity. It is made available under a CC-BY-NC-ND 4.0 International license .

Further analysis was restricted to the 155 studies with data collected from respiratory samples and that focused on the overall period of communicability, rather than solely on the convalescent period.

\section{Maximum reported durations of communicability.}

Out of 13 studies that successfully isolated and cultured virus from respiratory samples, the longest period that viable virus was able to be isolated from a case was 32 days after symptom onset; the median and mean durations for longest period of viral isolation across studies were 9 days (IQR 10) and 11.8 days (SD 8.47), respectively (Table 2). From the 133 studies with data on maximum duration of viral shedding from respiratory samples, the shortest reported time until viral clearance based on RT-PCR test results was five days from symptom onset, while the maximum was 95 days, with respective median and mean values of 24 and 28.7 days (IQR 19; SD 15.80). One study presented data on infectious period based on contact transmission; this study found that the longest time since symptom onset in the index case from which a secondary case was infected was five days [19].

\section{Findings from viral isolation studies.}

To assess how long viable virus could be obtained, considered as a proxy measure of infectious potential, we focused specifically on studies that investigated isolation and culturing of virus from respiratory samples $(n=16)$. Studies represented a mix of study designs (case reports, case series, and cross-sectional studies) and a wide range of sample sizes from which viral isolation was attempted (range 1-915) and/or successful (range 1-204). Studies determined duration of viral viability either by taking a cross-section of diagnostic samples collected at different times from symptom onset or by serially collecting samples from the same individuals over time; not all studies attempted viral isolation until viral clearance. Three studies were unable to isolate and culture any virus (Table 3).

Four studies reported viral isolation beyond 10 days. The longest period that virus could be cultured after symptom onset was 32 days, from hospitalized patients with severe disease; this was a study, comparing duration of viral culture from patients with mild or severe disease. A duration of 21 days was identified from a report of a single individual with mild symptoms but with significant underlying conditions including a recent heart transplant [15]. A separate case report of an individual without any significant comorbidities and also with mild disease symptoms reported viable virus until 18 days [20]. One case series of 129 hospitalized patients with moderate to severe disease, and mixed degrees of comorbidities, reported a maximum duration of viable virus of 20 days, with a median time to viral clearance of eight days [21].

The relationship between viral viability and symptom presentation was inconsistent. Some studies reported successful viral isolation from individuals who did not have symptoms at the time of sample collection $[12,15,20,22]$, others isolated viable virus from individuals who were symptomatic at the time of sample collection $[23,24]$, while other studies were unable to isolate virus from symptomatic individuals $[13,25]$ (Table 3). There were inconsistent data available on viral load and/or RT-PCR cycle threshold $(\mathrm{Ct})$ values and duration of viability, though a number of studies reported an upper limit on these measures for virus viability $[12,22,23,25-28]$. Few studies investigated seroconversion status and viral viability; one reported that seroconversion was associated with an inability to isolate virus [28] while others showed that virus continued to be isolated after detection of antibodies [21, 29]. A case report found that viral culture was successful while antibodies were not detectable, with seroconversion occurring later [24]. Finally, one study focused on pediatric populations reported viral viability from children as young as seven days of age [22].

Findings from studies investigating both viral isolation and viral shedding.

Page 6 of 34 
medRxiv preprint doi: https://doi.org/10.1101/2020.07.28.20163873; this version posted July 30, 2020. The copyright holder for this preprint (which was not certified by peer review) is the author/funder, who has granted medRxiv a license to display the preprint in perpetuity. It is made available under a CC-BY-NC-ND 4.0 International license .

A subset of these studies was further analyzed to compare the duration of viral nucleic acid shedding against the duration of virus viability. There were nine studies that provided data from respiratory samples on the duration of both viral nucleic acid shedding assessed by RT-PCR as well as viral isolation. All studies reported persistent viral shedding after virus was no longer able to be isolated and cultured (Figure 1). Across these studies, the median duration after symptom onset that virus was successfully isolated and cultured was 9 days, while the corresponding median value for longest duration until viral clearance by RT-PCR was 24 days (Figure 2).

\section{Findings from viral shedding studies with data on both maximum and median (or mean) durations of communicability.}

Finally, we explored how long it might take to achieve viral clearance based solely on detection of viral nucleic acid by RT-PCR tests. This analysis was specific to studies that reported measures of both central tendency (median, or mean when median was not reported) and maximum durations until viral clearance. Measures of central tendency can help to understand the population distribution in contrast to the maximum reported durations which are taken from a single data point/individual and thus more sensitive to outliers. Similarly, focusing on studies with multiple participants may provide more robust measures of time to viral clearance compared to case reports presenting data on single outlying individuals. Across these studies $(n=63)$, measurements of central tendency reported a median time to viral clearance of 15 days, while the median measurement for the longest reported time to viral clearance across all studies was 27 days (Figure 3).

We also stratified analyses by disease severity; however, data were limited there were only 30 studies where study populations could be identified as having had mild, moderate, or severe disease (Supplementary Figure 1). Fourteen studies each had populations with mild and moderate disease severity, while only two had populations with severe disease. Mean values for duration of median/mean viral shedding were 14 days (IQR 8.13), 15.5 days (IQR 9.25), and 24 days (IQR 7) for mild, moderate, and severe disease respectively. The median values for longest duration viral shedding from studies with mild, moderate, and severe disease were 20 (IQR 8.25), 26.5 (IQR 14), and 47.5 days (IQR 0.50).

\section{Discussion}

The results of this review present information relevant for policies on discontinuation of isolation for individuals infected with SARS-CoV-2. However, findings should be interpreted in light of significant limitations. There was a general paucity of high-quality evidence. Several of the included studies did not follow participants until viral clearance or collect samples at consistent intervals throughout the communicable period. We identified few studies that investigated viral isolation and many of the included studies had small sample sizes, making it difficult to draw robust findings from the n-of- 1 studies. The included studies suffer from selection bias and non-representative populations, as case reports and case series often focus on highly specific clinical populations and may bias toward incidences of prolonged viral shedding.

Findings from the available evidence support the general guidance of a minimum 10 day period of isolation [31]. Most studies showed an inability to isolate and culture virus beyond nine days. However, there should be additional precautions and longer observation considered for individuals being released into high-risk institutional settings such as long-term care facilities or those remaining in in-patient units, given that viable virus has been reported at 18 [30], 20 [21], 21 [15], and 32 days [28]. Notably, these positive findings were from individuals with mixed levels of underlying comorbidities, and who

Page 7 of 34 
medRxiv preprint doi: https://doi.org/10.1101/2020.07.28.20163873; this version posted July 30, 2020. The copyright holder for this preprint (which was not certified by peer review) is the author/funder, who has granted medRxiv a license to display the preprint in perpetuity. It is made available under a CC-BY-NC-ND 4.0 International license .

presented with heterogeneous disease profiles, from mild symptoms to severe complications and death associated with infection with SARS-CoV-2. An additional impetus for taking a precautionary approach is the inconsistency from studies reporting on symptomatology and viable virus; while some studies were not able to successfully culture virus from asymptomatic or post-symptomatic individuals [13,14], others successfully cultured virus from individuals who were not symptomatic at the time of specimen collection $[12,15]$.

Findings from this review also raise some limitations of fully relying on a RT-PCR-based strategy. Exploration of the potential duration of viral clearance by RT-PCR tests yielded a median duration of 15 days until viral clearance, which is in line with guidelines suggesting a 10-14 day isolation period. However, studies that presented data on both viral shedding and viral isolation demonstrate that individuals may continue to test positively on nucleic acid tests, after they are no longer infectious. In exceptional cases, viral shedding may persist for several weeks $[18,20,32-36]$.

While viral isolation and culture is a better proxy for understanding communicable period than detection of viral nucleic acid, it is not feasible to apply at scale in routine clinical practice. A number of commentaries and studies have suggested the use of additional metrics, such as disease severity [21,28], viral load [29], and presence of antibodies [21], in conjunction with a positive RT-PCR test, to help manage the issue of persistent viral shedding [37-39]. In the current study, analysis of papers with RT-PCR findings suggested a potential trend toward longer viral shedding with more severe disease; studies on viral isolation have further suggested a longer duration of viable viral shedding $[21,28]$. However, available data to assess this were limited and there is a scarcity of reliable evidence. Though a fulsome analysis on this topic was not conducted, findings on the relationship between seroconversion, viral load, and viral viability were inconsistent. It is anticipated that future studies will be able to provide more clarity on these issues.

There were a number of additional limitations identified in this rapid review. The included studies revealed heterogeneity in measurements of duration, including when measurement started and criteria for determining viral clearance. Some studies failed to clearly report their methods and so were unclear about when measurement started and/or ended or did not clearly report the type of sample collected (e.g., upper or lower respiratory tract). Additionally, many studies had incomplete follow-up. While studies reported a median or maximum duration of viral shedding, some only followed patients until the end of the study period rather than to an endpoint that consisted of reliable evidence of persistent viral clearance.

Our review is also limited by the need for timely appraisal of critical evidence for policy decisions and by the rapidly evolving literature. A rapid review aims to synthesize key information in a timely fashion and necessarily involves less comprehensive search methods than a systematic review. As a result of limiting the sensitivity of our search strategy and the sources searched, we may have missed some studies. Additionally, while we attempted to minimize the inclusion of repeated participants across studies by excluding studies analyzing secondary data, we did not investigate or contact authors to determine whether participants were included in multiple study populations. Also due to time constraints, we did not conduct a fulsome assessment of study quality. We found significant variations in study quality and a more detailed appraisal of study quality may reveal additional issues. Lastly, due to the rapidly growing literature on this topic, new studies have been released since the dates of our last searches $[40,41]$.

Despite the limitations raised above, this study is strengthened by the comprehensive and updated search strategy that was employed, the clear delineation of the question of interest and corresponding 
medRxiv preprint doi: https://doi.org/10.1101/2020.07.28.20163873; this version posted July 30, 2020. The copyright holder for this preprint (which was not certified by peer review) is the author/funder, who has granted medRxiv a license to display the preprint in perpetuity. It is made available under a CC-BY-NC-ND 4.0 International license .

specific criteria used for study inclusion, and the standardized data extraction that enabled the analyses presented herein. The raw data have been provided to assist other research and clinical teams who may find this detailed information helpful. This research highlights the critical need to update policies and practice through robust syntheses of newly emerging evidence. 
medRxiv preprint doi: https://doi.org/10.1101/2020.07.28.20163873; this version posted July 30, 2020. The copyright holder for this preprint (which was not certified by peer review) is the author/funder, who has granted medRxiv a license to display the preprint in perpetuity.

It is made available under a CC-BY-NC-ND 4.0 International license .

\section{REFERENCES}

1. WHO. Criteria for releasing COVID-19 patients from isolation [Internet]. Geneva, Switzerland: WHO; 2020 Jun [cited 2020 Jul 10]. Available from: https://www.who.int/publications-detailredirect/criteria-for-releasing-covid-19-patients-from-isolation

2. CDC. Discontinuation of Isolation for Persons with COVID -19 Not in Healthcare Settings [Internet]. Centers for Disease Control and Prevention. 2020 [cited 2020 Jul 10]. Available from: https://www.cdc.gov/coronavirus/2019-ncov/hcp/disposition-in-home-patients.html

3. European Centre for Disease Prevention and Control. Guidance for discharge and ending isolation in the context of widespread community transmission of COVID-19 - first update [Internet].

Stockholm: ECDC; 2020 Apr [cited 2020 May 19]. Available from: https://www.ecdc.europa.eu/en/publications-data/covid-19-guidance-discharge-and-endingisolation

4. Joynt GM, Wu WK. Understanding COVID-19: what does viral RNA load really mean? Lancet Infect Dis. 2020;20(6):635-636.

5. Experts question use of repeated Covid-19 tests after a patient recovers [Internet]. STAT. 2020 [cited $2020 \mathrm{Jul}$ 20]. Available from: https://www.statnews.com/2020/06/08/viral-shedding-covid19pcr-montreal-baby/

6. Weiss A, Jellingsoe M, Sommer MOA. Spatial and temporal dynamics of SARS-CoV-2 in COVID-19 patients: A systematic review. medRxiv: 20108605 [Preprint]. 2020 [cited 2020 Jul 10]. Available from: https://doi.org/10.1101/2020.05.21.20108605

7. Byrne AW, McEvoy D, Collins A, Hunt K, Casey M, Barber A, et al. Inferred duration of infectious period of SARS-CoV-2: rapid scoping review and analysis of available evidence for asymptomatic and symptomatic COVID-19 cases. medRxiv: 20079889 [Preprint]. 2020 [cited 2020 Jul 10]. Available from: https://doi.org/10.1101/2020.04.25.20079889

8. Dobbins M. Rapid Review Guidebook [Internet]. Hamilton, ON: National Collaborating Centre for Methods and Tools; 2017 [cited 2020 May 20]. Available from: https://www.nccmt.ca/capacitydevelopment/rapid-review-guidebook

9. Moher D, Liberati A, Tetzlaff J, Altman DG, Group TP. Preferred Reporting Items for Systematic Reviews and Meta-Analyses: The PRISMA Statement. PLOS Medicine. 2009 Jul 21;6(7):e1000097.

10. Hong QN, Fàbregues S, Bartlett G, Boardman F, Cargo M, Dagenais P, et al. The Mixed Methods Appraisal Tool (MMAT) version 2018 for information professionals and researchers. Education for Information. 2018 Jan 1;34(4):285-91.

11. R Core Team. R: A language and environment for statistical computing [Internet]. Vienna, Austria; 2020. Available from: http://www.R-project.org/

12. Arons MM, Hatfield KM, Reddy SC, Kimball A, James A, Jacobs JR, et al. Presymptomatic SARS-CoV-2 Infections and Transmission in a Skilled Nursing Facility. N Engl J Med. 2020;382:2081-2090. 
medRxiv preprint doi: https://doi.org/10.1101/2020.07.28.20163873; this version posted July 30, 2020. The copyright holder for this preprint (which was not certified by peer review) is the author/funder, who has granted medRxiv a license to display the preprint in perpetuity. It is made available under a CC-BY-NC-ND 4.0 International license .

13. Kumar DS, O'Neill SB, Johnston JC, Grant JM, Sweet DD. SARS-CoV-2 infection in a 76-year-old man with negative results for nasopharyngeal swabs and possible nosocomial transmission. CMAJ. 2020;192(20):E546-E549.

14. Million M, Lagier JC, Gautret P, Colson P, Fournier PE, Amrane S, et al. Early treatment of COVID-19 patients with hydroxychloroquine and azithromycin: A retrospective analysis of 1061 cases in Marseille, France. Travel Med Infect Dis. 2020 May;101738.

15. Decker A, Welzel M, Laubner K, Grundmann S, Kochs G, Panning M, et al. Prolonged SARS-CoV-2 shedding and mild course of COVID-19 in a patient after recent heart transplantation. Am J Transplant. 2020;00:1-7.

16. Sun J, Zhu A, Li H, Zheng K, Zhuang Z, Chen Z, et al. Isolation of infectious SARS-CoV-2 from urine of a COVID-19 patient. Emerg. 2020 Dec;9(1):991-3.

17. Xiao F, Sun J, Xu Y, Li F, Huang X, Li H, et al. Infectious SARS-CoV-2 in Feces of Patient with Severe COVID-19. Emerg Infect Dis. 2020 May 18;26(8):18.

18. Lu J, Peng J, Xiong Q, Liu Z, Lin H, Tan X, et al. Clinical, immunological and virological characterization of COVID-19 patients that test re-positive for SARS-CoV-2 by RT-PCR. medRxiv: 20131748 [Preprint]. 2020 [cited $2020 \mathrm{Jul} 10$ ]. Available from: https://doi.org/10.1101/2020.06.15.20131748

19. Cheng HY, Jian SW, Liu DP, Ng TC, Huang WT, Lin HH, et al. Contact tracing assessment of COVID-19 transmission dynamics in Taiwan and risk at different exposure periods before and after symptom onset [Internet]. JAMA Intern Med. 2020 [cited 2020 Jul 20]; Available from: https://doi.org/10.1001/jamainternmed.2020.2020

20. Liu W-D, Chang S-Y, Wang J-T, Tsai M-J, Hung C-C, Hsu C-L, et al. Prolonged Virus Shedding Even after Seroconversion in a Patient with COVID-19. J Infect. 2020 [cited 2020 Jul 20]; Available from: https://doi.org/10.1016/j.jinf.2020.03.063

21. van Kampen JJA van, Vijver DAMC van de, Fraaij PLA, Haagmans BL, Lamers MM, Okba N, et al. Shedding of infectious virus in hospitalized patients with coronavirus disease-2019 (COVID-19): duration and key determinants. medRxiv: 20125310 [Preprint]. 2020 [cited 2020 Jul 10]. Available from: https://doi.org/10.1101/2020.06.08.20125310

22. L'Huillier AG, Torriani G, Pigny F, Kaiser L, Eckerle I. Culture-Competent SARS-CoV-2 in Nasopharynx of Symptomatic Neonates, Children, and Adolescents. Emerg Infect Dis. 2020 Jun 30;26(10):30.

23. Lescure FX, Bouadma L, Nguyen D, Parisey M, Wicky PH, Behillil S, et al. Clinical and virological data of the first cases of COVID-19 in Europe: a case series. Lancet Infect Dis. 2020;20(6):P697-706.

24. Haveri A, Smura T, Kuivanen S, Osterlund P, Hepojoki J, Ikonen N, et al. Serological and molecular findings during SARS-CoV-2 infection: the first case study in Finland, January to February 2020. Euro Surveill. 2020;25(11):03.

25. Kim JY, Ko JH, Kim Y, Kim YJ, Kim JM, Chung YS, et al. Viral Load Kinetics of SARS-CoV-2 Infection in First Two Patients in Korea. J Korean Med Sci. 2020 Feb 24;35(7):e86. 
medRxiv preprint doi: https://doi.org/10.1101/2020.07.28.20163873; this version posted July 30, 2020. The copyright holder for this preprint (which was not certified by peer review) is the author/funder, who has granted medRxiv a license to display the preprint in perpetuity. It is made available under a CC-BY-NC-ND 4.0 International license .

26. Bullard J, Dust K, Funk D, Strong JE, Alexander D, Garnett L, et al. Predicting infectious SARS-CoV-2 from diagnostic samples. Clin Infect Dis. 2020;ciaa638.

27. Kujawski SA, Wong KK, Collins JP, Epstein L, Killerby ME, Midgley CM, et al. Clinical and virologic characteristics of the first 12 patients with coronavirus disease 2019 (COVID-19) in the United States. Nature Medicine. 2020 Jun;26(6):861-8.

28. Folgueira MD, Luczkowiak J, Lasala F, Perez-Rivilla A, Delgado R. Persistent SARS-CoV-2 replication in severe COVID-19. medRxiv: 20127837 [Preprint]. 2020 [cited $2020 \mathrm{Jul}$ 28]. Available from: https://www.medrxiv.org/content/10.1101/2020.06.10.20127837v1

29. Wölfel R, Corman VM, Guggemos W, Seilmaier M, Zange S, Müller MA, et al. Virological assessment of hospitalized patients with COVID-2019. Nature. 2020;581(7809):465-9.

30. Lui G, Ling L, Lai CK, Tso EY, Fung KS, Chan V, et al. Viral dynamics of SARS-CoV-2 across a spectrum of disease severity in COVID-19 [Internet]. J Infect. 2020. Available from: https://www.ncbi.nlm.nih.gov/pmc/articles/PMC7166038/

31. World Health Organization. Clinical management of COVID-19: interim guidance, 27 May 2020 [Internet]. Geneva: World Health Organization; 2020 [Cited 2020 Jul 10]. Available from: https://apps.who.int/iris/handle/10665/332196

32. Cao H, Ruan L, Liu J, Liao W. The clinical characteristic of eight patients of COVID-19 with positive RT-PCR test after discharge [Internet]. J Med Virol. 2020 [cited 2020 Jul 20]; Available from: https://www.ncbi.nlm.nih.gov/pmc/articles/PMC7272974/

33. Chen J, Xu X, Hu J, Chen Q, Xu F, Liang H, et al. Clinical Course and Risk Factors for Recurrence of Positive SARS-CoV-2 RNA: A Retrospective Cohort Study from Wuhan, China. medRxiv: 20095018 [Preprint]. 2020 [cited 2020 Jul 10]. Available from: https://doi.org/10.1101/2020.05.08.20095018

34. Li J, Zhang L, Liu B, Song D. Case Report: Viral Shedding for 60 Days in a Woman with Novel Coronavirus Disease (COVID-19). 2020;102(6):1210-1213.

35. Yang JR, Deng DT, Wu N, Yang B, Li HJ, Pan XB. Persistent viral RNA positivity during recovery period of a patient with SARS-CoV-2 infection [Internet]. J Med Virol. 2020 [cited 2020 Jul 20]; Available from: https://doi.org/10.1002/jmv.25940

36. Zhang M, Zhang J, Shi H, Liu B, Zeng F. Viral shedding prolongation in a kidney transplant patient with COVID-19 pneumonia [Internet]. Am J Transplant. 2020 [cited 2020 Jul 20]; Available from: https://pubmed.ncbi.nlm.nih.gov/32400931/

37. Bullard J, Dust K, Funk D, Strong JE, Alexander D, Garnett L, et al. Predicting infectious SARS-CoV-2 from diagnostic samples. Clin Infect Dis [Internet]. 2020 [cited 2020 Jul 20]; Available from: https://academic.oup.com/cid/article/doi/10.1093/cid/ciaa638/5842165

38. La Scola B, Le Bideau M, Andreani J, Hoang VT, Grimaldier C, Colson P, et al. Viral RNA load as determined by cell culture as a management tool for discharge of SARS-CoV-2 patients from infectious disease wards. Eur J Clin Microbiol Infect Dis. 2020 Jun 1;39(6):1059-61. 
medRxiv preprint doi: https://doi.org/10.1101/2020.07.28.20163873; this version posted July 30, 2020. The copyright holder for this preprint

(which was not certified by peer review) is the author/funder, who has granted medRxiv a license to display the preprint in perpetuity.

It is made available under a CC-BY-NC-ND 4.0 International license.

39. Joynt GM, Wu WK. Understanding COVID-19: what does viral RNA load really mean? The Lancet Infectious Diseases. 2020 Jun 1;20(6):635-6.

40. Vetter P, Eberhardt C, Meyer B, Martinez P, Torriani G, Pigny F, et al. Daily viral kinetics and innate and adaptive immune responses assessment in COVID-19: a case series. medRxiv: 20143271

[Preprint]. 2020 [cited 2020 Jul 28]. Available from:

https://www.medrxiv.org/content/10.1101/2020.07.02.20143271v1

41. Basile K, McPhie K, Carter I, Alderson S, Rahman H, Donovan L, et al. Cell-based culture of SARS-CoV2 informs infectivity and safe de-isolation assessments during COVID-19. medRxiv: 20153981

[Preprint]. 2020 [cited 2020 Jul 28]. Available from:

https://www.medrxiv.org/content/10.1101/2020.07.14.20153981v1

42. Chang, Zhao $P$, Zhang DW, Dong JH, Xu Z, Yang G, et al. Persistent viral presence determines the clinical course of the disease in COVID-19. J Allergy Clin Immunol Pract. 2020; [cited 2020 Jul 20]; Available from: https://doi.org/10.1016/j.jaip.2020.06.015

43. Gautret P, Lagier J-C, Parola P, Meddeb L, Sevestre J, Mailhe M, et al. Clinical and microbiological effect of a combination of hydroxychloroquine and azithromycin in 80 COVID-19 patients with at least a six-day follow up: A pilot observational study. Travel Med Infect Dis. 2020;101663. 
TABLES

Table 1. Characteristics of included studies, overall and broken down by method of assessment of duration of communicability.

\begin{tabular}{|c|c|c|c|c|c|c|c|c|c|c|}
\hline \multirow{2}{*}{ Sample size } & \multicolumn{2}{|c|}{ All studies $n=165$} & \multicolumn{2}{|c|}{$\begin{array}{c}\text { Contact } \\
\text { transmission } n=1\end{array}$} & \multicolumn{2}{|c|}{ Viral isolation $n=3$} & \multicolumn{2}{|c|}{$\begin{array}{c}\text { Viral shedding } \\
n=144\end{array}$} & \multicolumn{2}{|c|}{$\begin{array}{c}\text { Viral isolation and } \\
\text { shedding } n=17\end{array}$} \\
\hline & \multirow{5}{*}{\multicolumn{2}{|c|}{$\begin{array}{r}1 \\
2861 \\
71.98(245.78) \\
16(67.00)\end{array}$}} & \multirow{2}{*}{\multicolumn{2}{|c|}{2861}} & \multirow{2}{*}{\multicolumn{2}{|c|}{23}} & \multirow{2}{*}{\multicolumn{2}{|c|}{1}} & \multirow{2}{*}{\multicolumn{2}{|c|}{1}} \\
\hline Minimum & & & & & & & & & & \\
\hline Maximum & & & & & \multicolumn{2}{|r|}{129} & \multicolumn{2}{|r|}{584} & \multirow{3}{*}{\multicolumn{2}{|c|}{$\begin{array}{r}1061 \\
89.24(252.91) \\
9(75)\end{array}$}} \\
\hline Mean (SD) & & & & & & $72.33(53.40)$ & & $56(84.78)$ & & \\
\hline Median (IQR) & & & & & & $65(53.00)$ & & $15(65.25)$ & & \\
\hline Study design & $n$ & $\%$ & $\mathbf{n}$ & $\%$ & $\mathbf{n}$ & $\%$ & $n$ & $\%$ & 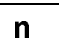 & $\%$ \\
\hline Case control & 2 & 1.21 & 0 & 0.00 & 0 & 0.00 & 2 & 1.39 & 0 & 0.00 \\
\hline Case report & 37 & 22.42 & 0 & 0.00 & 0 & 0.00 & 31 & 21.53 & 6 & 35.29 \\
\hline Case series & 104 & 63.03 & 1 & 100.00 & 2 & 66.67 & 92 & 68.89 & 9 & 52.94 \\
\hline Clinical trial & 3 & 1.82 & 0 & 0.00 & 0 & 0.00 & 3 & 2.08 & 0 & 0.00 \\
\hline Cohort & 15 & 9.09 & 0 & 0.00 & 0 & 0.00 & 15 & 10.42 & 0 & 0.00 \\
\hline Cross-sectional & 4 & 2.42 & 0 & 0.00 & 1 & 33.33 & 1 & 0.69 & 2 & 11.76 \\
\hline Measurement start & $\mathbf{n}$ & $\%$ & $n$ & $\%$ & $\mathbf{n}$ & $\%$ & $\mathbf{n}$ & $\%$ & $\mathbf{n}$ & $\%$ \\
\hline Hospital admission & 37 & 22.42 & 0 & 0.00 & 0 & 0.00 & 34 & 23.61 & 3 & 17.65 \\
\hline Date of $1^{\text {st }}$ positive test & 11 & 6.67 & 0 & 0.00 & 0 & 0.00 & 11 & 7.64 & 0 & 0.00 \\
\hline Symptom onset & 89 & 53.94 & 0 & 0.00 & 3 & 100.00 & 74 & 51.39 & 12 & 70.59 \\
\hline Other & 28 & 16.97 & 1 & 100.00 & 0 & 0.00 & 25 & 17.36 & 2 & 11.76 \\
\hline Measurement end & $\mathbf{n}$ & $\%$ & $n$ & $\%$ & $\mathbf{n}$ & $\%$ & $\mathbf{n}$ & $\%$ & $\mathbf{n}$ & $\%$ \\
\hline Negative test & 114 & 69.09 & 0 & 0.00 & 0 & 0.00 & 108 & 75.00 & 6 & 35.29 \\
\hline Discharge/death & 9 & 5.45 & 0 & 0.00 & 0 & 0.00 & 7 & 4.86 & 2 & 11.76 \\
\hline Last positive test & 6 & 3.64 & 0 & 0.00 & 0 & 0.00 & 5 & 3.47 & 1 & 5.88 \\
\hline Other & 36 & 21.82 & 1 & 100.00 & 3 & 100.00 & 24 & 16.67 & 8 & 47.06 \\
\hline Continent & $n$ & $\%$ & $n$ & $\%$ & $n$ & $\%$ & $n$ & $\%$ & $n$ & $\%$ \\
\hline Asia & 135 & 81.81 & 1 & 100.00 & 0 & 0.00 & 127 & 88.19 & 7 & 41.18 \\
\hline Australia & 1 & 0.61 & 0 & 0.00 & 0 & 0.00 & 1 & 0.69 & 0 & 0.00 \\
\hline Europe & 17 & 10.3 & 0 & 0.00 & 3 & 100.00 & 8 & 5.56 & 6 & 35.29 \\
\hline Middle East & 2 & 1.21 & 0 & 0.00 & 0 & 0.00 & 2 & 1.39 & 0 & 0.00 \\
\hline North America & 10 & 6.06 & 0 & 0.00 & 0 & 0.00 & 6 & 4.17 & 4 & 23.53 \\
\hline Age group & $n$ & $\%$ & $n$ & $\%$ & $n$ & $\%$ & $n$ & $\%$ & $n$ & $\%$ \\
\hline Children & 18 & 10.91 & 0 & 0.00 & 1 & 33.33 & 17 & 11.81 & 0 & 0.00 \\
\hline Adults & 118 & 71.52 & 0 & 0.00 & 2 & 66.67 & 102 & 70.83 & 14 & 82.35 \\
\hline
\end{tabular}

Page 1 of 34 


\begin{tabular}{|c|c|c|c|c|c|c|c|c|c|c|}
\hline \multirow[b]{2}{*}{ Mixed } & \multicolumn{2}{|c|}{ All studies $n=165$} & \multicolumn{2}{|c|}{$\begin{array}{c}\text { Contact } \\
\text { transmission } n=1\end{array}$} & \multicolumn{2}{|c|}{ Viral isolation $n=3$} & \multicolumn{2}{|c|}{$\begin{array}{c}\text { Viral shedding } \\
n=144\end{array}$} & \multicolumn{2}{|c|}{$\begin{array}{c}\text { Viral isolation and } \\
\text { shedding } n=17\end{array}$} \\
\hline & 29 & 17.58 & 1 & 100.00 & 0 & 0.00 & 25 & 17.36 & 3 & 17.65 \\
\hline Hospitalization status & $n$ & $\%$ & $n$ & $\%$ & $\mathbf{n}$ & $\%$ & $\mathbf{n}$ & $\%$ & $\mathbf{n}$ & $\%$ \\
\hline $\begin{array}{l}\text { Hospitalized } \\
\text { Non-hospitalized } \\
\text { Mixed } \\
\text { Unclear }\end{array}$ & $\begin{array}{l}140 \\
4 \\
15 \\
6\end{array}$ & $\begin{array}{l}84.85 \\
2.42 \\
9.09 \\
3.63\end{array}$ & $\begin{array}{l}0 \\
0 \\
0 \\
1\end{array}$ & $\begin{array}{l}0.00 \\
0.00 \\
0.00 \\
100.00\end{array}$ & $\begin{array}{l}3 \\
0 \\
0 \\
0\end{array}$ & $\begin{array}{l}100.00 \\
0.00 \\
0.00 \\
0.00\end{array}$ & $\begin{array}{l}124 \\
4 \\
12 \\
4\end{array}$ & $\begin{array}{l}86.11 \\
2.78 \\
8.33 \\
2.78\end{array}$ & $\begin{array}{l}14 \\
0 \\
2 \\
1\end{array}$ & $\begin{array}{l}82.35 \\
0.00 \\
11.76 \\
5.88\end{array}$ \\
\hline Disease severity & $n$ & $\%$ & $n$ & $\%$ & $\mathbf{n}$ & $\%$ & $n$ & $\%$ & $\mathbf{n}$ & $\%$ \\
\hline $\begin{array}{l}\text { Mild } \\
\text { Moderate } \\
\text { Severe } \\
\text { Mixed } \\
\text { Unclear }\end{array}$ & $\begin{array}{l}38 \\
35 \\
13 \\
47 \\
32\end{array}$ & \begin{tabular}{l|}
23.03 \\
21.21 \\
7.88 \\
28.48 \\
19.39
\end{tabular} & $\begin{array}{l}0 \\
0 \\
0 \\
0 \\
1\end{array}$ & $\begin{array}{l}0.00 \\
0.00 \\
0.00 \\
0.00 \\
100.00\end{array}$ & $\begin{array}{l}0 \\
0 \\
1 \\
1 \\
1\end{array}$ & \begin{tabular}{l|}
0.00 \\
0.00 \\
33.33 \\
33.33 \\
33.33
\end{tabular} & $\begin{array}{l}35 \\
31 \\
10 \\
41 \\
27\end{array}$ & \begin{tabular}{l|}
24.31 \\
21.53 \\
6.94 \\
28.47 \\
18.75
\end{tabular} & $\begin{array}{l}3 \\
4 \\
2 \\
5 \\
3\end{array}$ & \\
\hline Sample type & $n$ & $\%$ & $n$ & $\%$ & $\mathbf{n}$ & $\%$ & $n$ & $\%$ & $\mathbf{n}$ & $\%$ \\
\hline $\begin{array}{l}\text { Non-respiratory only } \\
\text { Respiratory + other } \\
\text { No sample }\end{array}$ & $\begin{array}{l}3 \\
161 \\
1\end{array}$ & $\begin{array}{l}1.82 \\
97.57 \\
0.61\end{array}$ & $\begin{array}{l}0 \\
0 \\
1\end{array}$ & $\begin{array}{l}0.00 \\
0.00 \\
100.00\end{array}$ & $\begin{array}{l}0 \\
3 \\
0\end{array}$ & $\begin{array}{l}0.00 \\
100.00 \\
0.00\end{array}$ & $\begin{array}{l}2 \\
142 \\
0\end{array}$ & $\begin{array}{l}1.39 \\
98.61 \\
0.00\end{array}$ & $\begin{array}{l}1 \\
16 \\
0\end{array}$ & $\begin{array}{l}5.88 \\
94.12 \\
0.00\end{array}$ \\
\hline $\begin{array}{l}\text { Focused on Convalescent Period } \\
\text { Only }\end{array}$ & $\mathbf{n}$ & $\%$ & $\mathbf{n}$ & $\%$ & $\mathbf{n}$ & $\%$ & $n$ & $\%$ & $n$ & $\%$ \\
\hline $\begin{array}{l}\text { Yes } \\
\text { No }\end{array}$ & $\begin{array}{l}7 \\
158\end{array}$ & $\begin{array}{l}4.24 \\
95.76\end{array}$ & $\begin{array}{l}0 \\
1\end{array}$ & $\begin{array}{l}0.00 \\
100.00\end{array}$ & $\begin{array}{l}0 \\
3\end{array}$ & $\begin{array}{l}0.00 \\
100.00\end{array}$ & $\begin{array}{l}6 \\
138 \\
\end{array}$ & $\begin{array}{l}4.17 \\
95.83\end{array}$ & $\begin{array}{l}1 \\
16\end{array}$ & $\begin{array}{l}5.88 \\
94.12\end{array}$ \\
\hline $\begin{array}{l}\text { Includes Asymptomatic or Pre- } \\
\text { Symptomatic cases }\end{array}$ & n & $\%$ & $\mathbf{n}$ & $\%$ & $\mathbf{n}$ & $\%$ & $n$ & $\%$ & $\mathbf{n}$ & $\%$ \\
\hline $\begin{array}{l}\text { Yes } \\
\text { No }\end{array}$ & $\begin{array}{l}73 \\
92\end{array}$ & $\begin{array}{l}44.24 \\
55.76\end{array}$ & $\begin{array}{l}1 \\
0\end{array}$ & $\begin{array}{l}100.00 \\
0.00\end{array}$ & $\begin{array}{l}0 \\
3\end{array}$ & $\begin{array}{l}0.00 \\
100.00\end{array}$ & $\begin{array}{l}68 \\
76\end{array}$ & $\begin{array}{l}47.22 \\
52.78\end{array}$ & $\begin{array}{l}4 \\
13\end{array}$ & $\begin{array}{l}23.53 \\
76.47\end{array}$ \\
\hline Publication status & $\mathbf{n}$ & $\%$ & $\mathbf{n}$ & $\%$ & $\mathbf{n}$ & $\%$ & $n$ & $\%$ & $\mathbf{n}$ & $\%$ \\
\hline $\begin{array}{l}\text { Peer-reviewed journal } \\
\text { Pre-print database }\end{array}$ & $\begin{array}{l}139 \\
26\end{array}$ & $\begin{array}{l}84.24 \\
15.76\end{array}$ & $\begin{array}{l}1 \\
0\end{array}$ & $\begin{array}{l}100.00 \\
0.00\end{array}$ & $\begin{array}{l}1 \\
2\end{array}$ & $\begin{array}{l}33.33 \\
66.67\end{array}$ & $\begin{array}{l}121 \\
23\end{array}$ & $\begin{array}{l}84.03 \\
15.97\end{array}$ & $\begin{array}{l}16 \\
1\end{array}$ & $\begin{array}{l}94.12 \\
5.88\end{array}$ \\
\hline Study Quality & $\mathbf{n}$ & $\%$ & $n$ & $\%$ & $\mathbf{n}$ & $\%$ & $\mathbf{n}$ & $\%$ & $\mathbf{n}$ & $\%$ \\
\hline $\begin{array}{l}0 \text { quality concerns } \\
1 \text { quality concern } \\
2 \text { quality concerns } \\
3 \text { quality concerns } \\
4 \text { quality concerns }\end{array}$ & $\begin{array}{l}30 \\
43 \\
52 \\
32 \\
6\end{array}$ & $\begin{array}{l}18.18 \\
26.06 \\
31.51 \\
19.39 \\
3.63\end{array}$ & $\begin{array}{l}1 \\
0 \\
0 \\
0 \\
0\end{array}$ & $\begin{array}{l}100.00 \\
0.00 \\
0.00 \\
0.00 \\
0.00\end{array}$ & $\begin{array}{l}1 \\
1 \\
1 \\
0 \\
0\end{array}$ & $\begin{array}{l}33.33 \\
33.33 \\
33.33 \\
0.00 \\
0.00\end{array}$ & $\begin{array}{l}26 \\
37 \\
45 \\
28 \\
6\end{array}$ & $\begin{array}{l}18.06 \\
25.69 \\
31.25 \\
19.44 \\
4.17\end{array}$ & $\begin{array}{l}2 \\
5 \\
6 \\
4 \\
0\end{array}$ & $\begin{array}{l}11.76 \\
29.41 \\
35.29 \\
23.53 \\
0.00\end{array}$ \\
\hline
\end{tabular}

Page 2 of 34 


\begin{tabular}{|c|c|c|c|c|c|c|c|c|c|c|}
\hline & \multicolumn{2}{|c|}{ All studies $n=165$} & \multicolumn{2}{|c|}{$\begin{array}{c}\text { Contact } \\
\text { transmission } n=1\end{array}$} & \multicolumn{2}{|c|}{ Viral isolation $n=3$} & \multicolumn{2}{|c|}{$\begin{array}{c}\text { Viral shedding } \\
n=144\end{array}$} & \multicolumn{2}{|c|}{$\begin{array}{l}\text { Viral isolation and } \\
\text { shedding } n=17\end{array}$} \\
\hline 5 quality concerns & 2 & 1.21 & 0 & 0.00 & 0 & 0.00 & 2 & 1.39 & 0 & 0.00 \\
\hline
\end{tabular}


Table 2. Summary statistics on duration of maximum duration of communicability from studies reporting on contact transmission, isolation and culture of live virus from respiratory samples, and detection of viral shedding by RT-PCR from respiratory samples. Note that some studies provided data for both viral isolation and viral shedding.

\begin{tabular}{|l|r|r|r|r|r|}
\hline \multicolumn{1}{|c|}{ Method of analysis } & $\begin{array}{c}\text { Number of included } \\
\text { studies }\end{array}$ & $\begin{array}{c}\text { Shortest maximum } \\
\text { reported duration }\end{array}$ & $\begin{array}{c}\text { Mean maximum } \\
\text { reported duration (SD) }\end{array}$ & $\begin{array}{c}\text { Median maximum } \\
\text { reported duration (IQR) }\end{array}$ & $\begin{array}{c}\text { Longest maximum } \\
\text { reported duration }\end{array}$ \\
\hline Contact Transmission & 1 & $\mathrm{n} / \mathrm{a}$ & $\mathrm{n} / \mathrm{a}$ & $\mathrm{n} / \mathrm{a}$ & 5 \\
\hline Viral Isolation & 13 & 2 & $28.8(8.47)$ & $24(19)$ & \\
\hline Viral Shedding & 133 & 5 & $28.7(15.80)$ & 95 \\
\hline IQR = interquartile range; SD = standard deviation
\end{tabular}


Table 3. Detailed data from papers investigating durations until viral isolation and culture. Papers are presented in alphabetical order by first author.

\begin{tabular}{|c|c|c|c|c|c|c|c|c|c|}
\hline $\begin{array}{l}\text { First Author } \\
\text { Journal \& } \\
\text { publication } \\
\text { date/status }\end{array}$ & Country & $\begin{array}{l}\text { Study } \\
\text { design }\end{array}$ & Study population & $\begin{array}{l}\text { Sample } \\
\text { Size }\end{array}$ & $\begin{array}{l}\text { Sample types } \\
\text { taken for } \\
\text { isolation, } \\
\text { sampling } \\
\text { method }\end{array}$ & $\begin{array}{l}\text { Viral } \\
\text { shedding } \\
\text { (max) }\end{array}$ & $\begin{array}{l}\text { Viral } \\
\text { isolation } \\
\text { (max) }\end{array}$ & Notable findings & Symptoms \\
\hline $\begin{array}{l}\text { Arons et } \\
\text { al.(12) } \\
\text { New England } \\
\text { Journal of } \\
\text { Medicine } \\
\text { (April 24, } \\
2020 \text { ) }\end{array}$ & $\begin{array}{l}\text { United } \\
\text { States }\end{array}$ & $\begin{array}{l}\text { Serial } \\
\text { cross- } \\
\text { section } \\
\text { al }\end{array}$ & $\begin{array}{l}\text { Patients in a skilled } \\
\text { nursing facility with } \\
\text { mixed disease } \\
\text { severity, a mean age } \\
\text { of } 78.6,98 \% \text { had a co- } \\
\text { morbidity }\end{array}$ & $\begin{array}{l}48 \text { ( } 27 \\
\text { individu } \\
\text { als with } \\
2 \\
\text { samples } \\
\text { taken) }\end{array}$ & $\begin{array}{l}\text { NP \& OP } \\
\text { samples, } \\
\text { collected at } 2 \\
\text { time points, } \\
1 \text { week apart. }\end{array}$ & 13 days & 9 days & $\begin{array}{l}\text { Positive cultures in } 17 \text { out } \\
\text { of } 24 \text { pre-symptomatic } \\
\text { patents and } 1 \text { out of } 3 \\
\text { asymptomatic patients. } \\
\text { Viable virus isolated up to } \\
6 \text { days before onset of } \\
\text { symptoms. RT-PCR } \\
\text { positive up to } 7 \text { days prior } \\
\text { to symptom onset. } \\
\text { RT-PCR Ct values ranged } \\
\text { from } 13.7-37.9 \text { in positive } \\
\text { samples. }\end{array}$ & $\begin{array}{l}\text { Includes asymptomat } \\
\text { and pre-symptomatic } \\
\text { patients. Most comm } \\
\text { new symptoms were } \\
\text { fever, cough and } \\
\text { malaise. }\end{array}$ \\
\hline $\begin{array}{l}\text { Bullard et al. } \\
(26) \\
\text { Clinical } \\
\text { Infectious } \\
\text { Diseases (May } \\
22,2020)\end{array}$ & Canada & $\begin{array}{l}\text { Cross- } \\
\text { section } \\
\text { al }\end{array}$ & $\begin{array}{l}\text { All samples in this } \\
\text { study were obtained } \\
\text { to support routine } \\
\text { care and surveillance } \\
\text { of the public health } \\
\text { response in the } \\
\text { province of Manitoba, } \\
\text { Canada. All suspect } \\
\text { COVID-19 cases had } \\
\text { SARS-CoV-2 RT-PCR } \\
\text { performed on } \\
\text { nasopharyngeal (NP) } \\
\text { or endotracheal (ETT) } \\
\text { samples at Cadham } \\
\text { Provincial Laboratory. }\end{array}$ & $\begin{array}{l}90(26 \\
\text { with } \\
\text { positive } \\
\text { viral } \\
\text { isolation } \\
\text { ) }\end{array}$ & $\begin{array}{l}\text { NP and } \\
\text { endotracheal } \\
\text { samples, } \\
\text { from } \\
\text { diagnostic } \\
\text { samples of } \\
\text { individuals } \\
\text { who tested } \\
\text { positive by } \\
\text { RT-PCR from } \\
\text { day } 0 \text { to } 21 \\
\text { post } \\
\text { symptom } \\
\text { onset }\end{array}$ & 21 days & 8 days & $\begin{array}{l}\text { Positive viral culture } \\
\text { samples had significantly } \\
\text { lower Ct values than } \\
\text { negative cultures (17 (16- } \\
\text { 19) vs } 27 \text { (22-33)). For } \\
\text { every increase in unit in Ct } \\
\text { value, the odds of a } \\
\text { positive culture decreased } \\
\text { by } 32 \% \text {. } \\
\text { Time from symptom to } \\
\text { test time was significantly } \\
\text { lower in positive vs } \\
\text { negative cultures ( } 3 \text { (2-4) } \\
\text { vs } 7 \text { (2-11)). For every day }\end{array}$ & Not described. \\
\hline
\end{tabular}




\begin{tabular}{|c|c|c|c|c|c|c|c|c|c|}
\hline & & & $\begin{array}{l}\text { Median age of the } \\
\text { patients sampled was } \\
45 \text { (range: } 30-59 \\
\text { years). Forty } \\
\text { nine percent of } \\
\text { samples were from } \\
\text { males. }\end{array}$ & & & & & $\begin{array}{l}\text { since symptom the odds of } \\
\text { a positive culture } \\
\text { decreased by } 37 \% \text {. } \\
\text { Probability of a successful } \\
\text { positive culture peaked on } \\
\text { day } 3 \text { and decreased after } \\
\text { that point. } \\
\text { No growth in samples with } \\
\mathrm{Ct}>24 \text {. }\end{array}$ & \\
\hline $\begin{array}{l}\text { Chang et al. } \\
\text { (42) } \\
\text { The Journal of } \\
\text { Allergy and } \\
\text { Clinical } \\
\text { Immunology } \\
\text { in Practice } \\
\text { (June 20, } \\
\text { 2020) }\end{array}$ & China & $\begin{array}{l}\text { Case } \\
\text { series }\end{array}$ & $\begin{array}{l}\text { Hospitalized patients } \\
\text { with mixed disease } \\
\text { severity, who re- } \\
\text { tested positive after } \\
\text { discharge. } 3 \text { required } \\
\text { ICU admission. }\end{array}$ & $\begin{array}{l}69 \text { (4 } \\
\text { attempt } \\
\text { ed and } 0 \\
\text { positive } \\
\text { viral } \\
\text { isolation } \\
\text { s) }\end{array}$ & $\begin{array}{l}\text { Throat } \\
\text { samples, } \\
\text { collected } \\
\text { serially while } \\
\text { in hospital } \\
\text { and after } \\
\text { discharge. } \\
\text { Only } \\
\text { attempted } \\
\text { viral isolation } \\
\text { from samples } \\
\text { taken during } \\
\text { the } \\
\text { convalescent } \\
\text { period, sent } \\
\text { while } \\
\text { patients } \\
\text { were at } \\
\text { home. }\end{array}$ & 57 days & $\mathrm{N} / \mathrm{A}$ & $\begin{array}{l}\text { No positive viral isolation/ } \\
\text { culture during } \\
\text { convalescent period. }\end{array}$ & $\begin{array}{l}\text { Fever present in } 82 \% \\
\text { patients, cough in } 60 \% \\
\text { of patients, sputum in } \\
25 \% .2 \text { patients were } \\
\text { asymptomatic. }\end{array}$ \\
\hline $\begin{array}{l}\text { Decker et al. } \\
\text { (15) } \\
\text { American } \\
\text { Journal of } \\
\text { Transplantati } \\
\text { on (June, }\end{array}$ & Germany & $\begin{array}{l}\text { Case } \\
\text { report }\end{array}$ & $\begin{array}{l}62 \text { year old male heart } \\
\text { transplant recipient } \\
\text { who was hospitalized } \\
\text { with mild disease } \\
\text { severity }\end{array}$ & 1 & $\begin{array}{l}\text { Throat } \\
\text { samples, } \\
\text { collected } \\
\text { serially at } 10 \\
\text { time points } \\
\text { until day } 35 \\
\text { of illness. }\end{array}$ & $\begin{array}{l}>35 \text { days } \\
\text { (patient } \\
\text { still } \\
\text { testing } \\
\text { positive at } \\
\text { study end) }\end{array}$ & 21 days & $\begin{array}{l}\text { Patient post-symptomatic } \\
\text { at time of positive viral } \\
\text { cultures. }\end{array}$ & $\begin{array}{l}\text { Fever on day } 1 \text { that } \\
\text { resolved within } 12 \\
\text { hours, second fever } \\
\text { that spiked and } \\
\text { resolved at day } 7 . \\
\text { Other symptoms were } \\
\text { mild rhinorrhea and }\end{array}$ \\
\hline
\end{tabular}




\begin{tabular}{|c|c|c|c|c|c|c|c|c|c|}
\hline 2020) & & & & & & & & & $\begin{array}{l}\text { impaired exercise } \\
\text { capacity. }\end{array}$ \\
\hline $\begin{array}{l}\text { Folgueira et } \\
\text { al. (28) } \\
\text { MedrXiv* Pre- } \\
\text { print (June 12, } \\
\text { 2020) }\end{array}$ & Spain & $\begin{array}{l}\text { Cross- } \\
\text { section } \\
\text { al }\end{array}$ & $\begin{array}{l}\text { Patients with mixed } \\
\text { disease severity. } \\
\text { Patients with mild } \\
\text { symptoms }(n=24) \\
\text { were healthcare } \\
\text { workers, largely } \\
\text { women, and assessed } \\
\text { in outpatient settings. } \\
\text { Patients with severe } \\
\text { disease were } \\
\text { hospitalized ( } n=41) \text {, of } \\
\text { which } 5 \text { died. }\end{array}$ & $\begin{array}{l}65 \text { (106 } \\
\text { samples } \\
\text { taken) }\end{array}$ & $\begin{array}{l}\text { NP samples } \\
\text { and bronchial } \\
\text { aspirates, } \\
\text { from } \\
\text { diagnostic } \\
\text { samples of } \\
\text { individuals } \\
\text { diagnosed as } \\
\text { outpatients } \\
\text { and those } \\
\text { followed up } \\
\text { for hospital } \\
\text { care. Median } \\
\text { time of } \\
\text { sample } \\
\text { collection for } \\
\text { hospitalized } \\
\text { patients was } \\
\text { 19.6 days } \\
\text { and for } \\
\text { outpatients } \\
\text { was } 16.5 \\
\text { days. }\end{array}$ & 32 days & $N / A$ & $\begin{array}{l}\text { Positive viral culture was } \\
\text { obtained from a higher } \\
\text { proportion of patients } \\
\text { with severe disease vs } \\
\text { mild symptoms ( } 53.4 \% \text { of } \\
\text { samples vs } 36.0 \% \text { ). All } \\
\text { samples from deceased } \\
\text { patients were able to be } \\
\text { cultured. } \\
\text { Samples with Ct values < } \\
25 \text { had }>90 \% \text { positive viral } \\
\text { culture. However, samples } \\
\text { with low viral loads (Ct > } \\
35 \text { ) could still harbor } \\
\text { viable virus. }\end{array}$ & 6 hospitalized patient禺 \\
\hline $\begin{array}{l}\text { Kumar et al. } \\
(13) \\
\text { Canadian } \\
\text { Medical } \\
\text { Association } \\
\text { Journal (April } \\
24,2020)\end{array}$ & Canada & $\begin{array}{l}\text { Case } \\
\text { report }\end{array}$ & $\begin{array}{l}76 \text { year old man with } \\
\text { multiple } \\
\text { comorbidities, who } \\
\text { initially tested } \\
\text { negative for COVID- } \\
19 .\end{array}$ & 1 & $\begin{array}{l}\text { NP sample, } \\
\text { collected on } \\
\text { day } 4 \text { of } \\
\text { hospital } \\
\text { admission } \\
\text { (which was } \\
11 \text { days after } \\
\text { exposure, } \\
\text { and day } 6 \\
\text { after cough } \\
\text { worsened) }\end{array}$ & 17 days & N/A & $\begin{array}{l}\text { No positive viral isolation/ } \\
\text { culture. } \\
\text { Sputum culture conducted } \\
\text { on day } 4 \text {, which is the } \\
\text { same day that patient } \\
\text { tested negative for SARS- } \\
\text { CoV-2 in a NP swab. NP } \\
\text { swab, positive on day } 7 \text { of } \\
\text { admission (18 days after } \\
\text { exposure; } 13 \text { days after } \\
\text { cough worsened) }\end{array}$ & $\begin{array}{l}\text { Worsening cough on } \\
\text { days 1-6, fatigue, } \\
\text { exertional dyspnea, } \\
\text { fevers, low appetite } \\
\text { and diarrhea on days } 2 \\
6\end{array}$ \\
\hline
\end{tabular}

Page 7 of 34 


\begin{tabular}{|c|c|c|c|c|c|c|c|c|c|}
\hline $\begin{array}{l}\text { Gautret et al. } \\
\text { (43) } \\
\text { Travel } \\
\text { Medicine and } \\
\text { Infectious } \\
\text { diseases (April } \\
\text { 2020) }\end{array}$ & France & $\begin{array}{l}\text { Case } \\
\text { series }\end{array}$ & $\begin{array}{l}\text { Hospitalized patients } \\
\text { with age range of } 18 \\
\text { to } 88 \text { years, } 57.5 \% \text { had } \\
\text { at least one } \\
\text { comorbidity. } 3 \\
\text { patients were } \\
\text { transferred to ICU, } 1 \\
\text { patients died. }\end{array}$ & $\begin{array}{l}80(53 \\
\text { with } \\
\text { positive } \\
\text { viral } \\
\text { isolation } \\
\text { ) }\end{array}$ & $\begin{array}{l}\text { NP samples, } \\
\text { collected } \\
\text { daily } \\
\text { beginning at } \\
\text { treatment. }\end{array}$ & 12 days & 9 days & $\begin{array}{l}\text { Viral cultures were } \\
\text { negative in } 97.5 \% \text { of } \\
\text { patients at day } 5 .\end{array}$ & $\begin{array}{l}4 \text { patients were } \\
\text { asymptomatic, } 14 \\
\text { patients had fever as a } \\
\text { symptom, } 33 \text { had upper } \\
\text { respiratory tract } \\
\text { symptoms and } 43 \text { had } \\
\text { lower respiratory tract } \\
\text { symptoms. }\end{array}$ \\
\hline $\begin{array}{l}\text { Haveri et al. } \\
(24) \\
\text { Euro } \\
\text { Surveillance } \\
\text { (Mar 25, } \\
2020)\end{array}$ & Finland & $\begin{array}{l}\text { Case } \\
\text { report }\end{array}$ & $\begin{array}{l}\text { First COVID-19 case in } \\
\text { Finland. Hospitalized } \\
\text { woman in her } 30 \text { s } \\
\text { from Wuhan with mild } \\
\text { disease severity. }\end{array}$ & 1 & $\begin{array}{l}\text { NP samples, } \\
\text { collected } \\
\text { serially, on } \\
\text { days } 3,4,9 \text {, } \\
10,20 \text { and } \\
23, \text { unclear } \\
\text { when viral } \\
\text { isolation was } \\
\text { attempted. }\end{array}$ & 8 days & 4 days & $\begin{array}{l}\text { Showed late } \\
\text { seroconversion: } \\
\text { Antibodies were } \\
\text { undetectable on Day } 4 \\
\text { after onset of symptoms, } \\
\text { IgG titres rose to } 80 \text { and } \\
\text { 1,280 and IgM titres to } 80 \\
\text { and } 320 \text { on Days } 9 \text { and } 20 . \\
\text { Ct values on day } 4 \text { for } \\
\text { different RT-PCR targets: E } \\
\text { (29.59), RdRp (30.87), N } \\
\text { (31.78). }\end{array}$ & $\begin{array}{ll} & \\
\text { Respiratory symptom } & \\
\text { on onset, followed by } \\
\text { high fever on day 2, } \\
\text { post-symptomatic by } \\
\text { day 7. }\end{array}$ \\
\hline $\begin{array}{l}\text { Kim et al. (25) } \\
\text { J Korean Med } \\
\text { Sci (Feb 24, } \\
2020)\end{array}$ & $\begin{array}{l}\text { South } \\
\text { Korea }\end{array}$ & $\begin{array}{l}\text { Case } \\
\text { series }\end{array}$ & $\begin{array}{l}\text { First } 2 \text { patients with } \\
\text { COVID-19 in South } \\
\text { Korea. } 135 \text {-year old } \\
\text { woman and } 155 \text {-year } \\
\text { old man, both with } \\
\text { mild symptoms. }\end{array}$ & 2 & $\begin{array}{l}\text { Respiratory } \\
\text { samples, } \\
\text { collected } \\
\text { daily starting } \\
\text { day } 2 \text { and } \\
\text { day } 14 \text { of } \\
\text { illness. }\end{array}$ & 26 days & $N / A$ & $\begin{array}{l}\text { No positive viral isolation/ } \\
\text { culture. } \\
\text { Upper respiratory RdRp Ct } \\
\text { values ranged from 25.05- } \\
36.69 \text { and lower } \\
\text { respiratory RdRp Ct values } \\
\text { ranged from 22.05-32.63. }\end{array}$ & $\begin{array}{l}\text { Patient } 1 \text { had fever at } \\
\text { onset of illness until } \\
\text { day } 9 \text {, nasal congestio } \\
\text { on days } 6-8 \text {, dyspnea } \\
\text { on days } 9-11 \text {, cough of } \\
\text { days } 7-13 \text {, sputum on } \\
\text { days } 9-13 \text { and mild } \\
\text { loose stools on days } \\
\text { 19. Patient } 2 \text { had sore } \\
\text { throat from illness } \\
\text { onset until day } 17 \text {, } \\
\text { fever beginning around } \\
\text { day } 10 \text { and lasting until } \\
\text { 16, cough on days } 16- \\
\text { 18 and loose stool on } \\
\text { days } 19-21 \text {. }\end{array}$ \\
\hline
\end{tabular}




\begin{tabular}{|c|c|c|c|c|c|c|c|c|c|}
\hline $\begin{array}{l}\text { Kujawski et al. } \\
(27) \\
\text { Nature (June } \\
26,2020)\end{array}$ & $\begin{array}{l}\text { United } \\
\text { States }\end{array}$ & $\begin{array}{l}\text { Case } \\
\text { series }\end{array}$ & $\begin{array}{l}\text { Convenience sample } \\
\text { of the first } 12 \text { US } \\
\text { patients confirmed to } \\
\text { have COVID-19. } 5 \\
\text { patients had } \\
\text { underlying conditions. } \\
\text { Median age was } 53 \\
\text { years (range: } 21-68 \text { ); } \\
8 \text { patients were male. } \\
\text { Had mild to moderate } \\
\text { illness with } 7 \text { patients } \\
\text { hospitalized but none } \\
\text { requiring mechanical } \\
\text { ventilation and all } \\
\text { showing recovery. }\end{array}$ & $\begin{array}{l}12 \text { (9 } \\
\text { with } \\
\text { positive } \\
\text { viral } \\
\text { isolation } \\
\text { ) }\end{array}$ & $\begin{array}{l}\text { NP and OP } \\
\text { samples, } \\
\text { which were } \\
\text { taken on } \\
\text { days 1-9 } \\
\text { from } \\
\text { symptom } \\
\text { onset. Not } \\
\text { attempted in } \\
\text { later } \\
\text { specimens. }\end{array}$ & 29 days & 9 days & $\begin{array}{l}\text { Positive viral isolation } \\
\text { from samples with RT-PCR } \\
\text { Ct values of } 12.3-35.7 \text {. }\end{array}$ & $\begin{array}{l}\text { Median symptom } \\
\text { duration of } 14 \text { days, } \\
\text { cough reported as last } \\
\text { symptom to resolve. } \\
\text { Median duration of } \\
\text { fever was } 9 \text { days (range } \\
\text { 2-11), with a peak body } \\
\text { temperature at mediam } \\
9 \text { days (range 4-10) } \\
\end{array}$ \\
\hline $\begin{array}{l}\text { Lescure et al. } \\
(23) \\
\text { Lancet } \\
\text { Infectious } \\
\text { Diseases (Mar } \\
27,2020)\end{array}$ & France & $\begin{array}{l}\text { Case } \\
\text { series }\end{array}$ & $\begin{array}{l}\text { Patients were three } \\
\text { men (aged } 31 \text { years, } \\
48 \text { years, and } 80 \\
\text { years) and two } \\
\text { women (aged } 30 \text { years } \\
\text { and } 46 \text { years). }\end{array}$ & 5 & $\begin{array}{l}\text { NP samples, } \\
\text { taken from } \\
\text { patients once } \\
\text { only at days } \\
2,2,6,7,9 \\
\text { since } \\
\text { symptom } \\
\text { onset. }\end{array}$ & $\begin{array}{l}24 \text { days } \\
\text { (until } \\
\text { patient } \\
\text { death) }\end{array}$ & 2 days & $\begin{array}{l}\text { Positive viral isolation in } \\
\text { samples with RdRp Ct } \\
\text { values of } 23.6 \text { and } 24.4, \mathrm{E} \\
\text { gene Ct of } 22.8 \text { and } 20.0 \text {, } \\
\text { RdRp IP Ct of } 23.0 \text { and } \\
\text { 19.3, GAPDH } \\
\text { (housekeeping gene) Ct of } \\
26.5 \text { and } 25.6 \text {. } \\
\text { Positive isolate titre was } \\
6.25 \times 10^{5} \text { and } 3.0 \times 10^{7} \text {. }\end{array}$ & $\begin{array}{l}\text { Describes } 3 \text { subtypes } \\
\text { symptom progression } \\
\text { first, mild cases } \\
\text { through two } \\
\text { paucisymptomatic } \\
\text { patients aged young } \\
\text { than } 50 \text { years who } \\
\text { were diagnosed early, } \\
\text { with high viral load in } \\
\text { nasopharyngeal } \\
\text { samples, suggesting a } \\
\text { significant shedding of } \\
\text { SARS-CoV-2, reflected } \\
\text { by virus detection by } \\
\text { RT-PCR; second, two } \\
\text { young patients } \\
\text { presenting with mild } \\
\text { symptoms at admission } \\
\text { and experiencing a } \\
\text { secondary progression } \\
\text { to pneumonia and } \\
\text { severe disease by days } \\
\text { 10-11; and third, an }\end{array}$ \\
\hline
\end{tabular}




\begin{tabular}{|c|c|c|c|c|c|c|c|c|c|}
\hline & & & & & & & & & $\begin{array}{l}\text { older patient with a } \\
\text { rapid evolution towar } \\
\text { critical disease with } \\
\text { multiple organ failure } \\
\text { and a long and } \\
\text { sustained persistence } \\
\text { of SARS-CoV-2 } \\
\text { nasopharyngeal } \\
\text { detection associated } \\
\text { with viral RNA } \\
\text { detection in multiple } \\
\text { sites }\end{array}$ \\
\hline $\begin{array}{l}\text { L'Huillier et al } \\
\text { (22) } \\
\text { Emerging } \\
\text { Infectious } \\
\text { Diseases (June } \\
30,2020 \text { ) }\end{array}$ & $\begin{array}{l}\text { Switzerla } \\
\text { nd }\end{array}$ & $\begin{array}{l}\text { Case } \\
\text { series }\end{array}$ & $\begin{array}{l}\text { Children with mild } \\
\text { disease. Isolated virus } \\
\text { from children of all } \\
\text { ages; the youngest } \\
\text { was } 7 \text { days of age }\end{array}$ & $\begin{array}{l}23(12 \\
\text { with } \\
\text { positive } \\
\text { viral } \\
\text { isolation } \\
\text { ) }\end{array}$ & $\begin{array}{l}\text { NP samples, } \\
\text { taken from } \\
\text { patients at } \\
\text { days } 0 \text { - } 5 \\
\text { after } \\
\text { symptom } \\
\text { onset. Did } \\
\text { not attempt } \\
\text { after day } 5 .\end{array}$ & N/A & 5 days & $\begin{array}{l}\text { Median viral load was } \\
\text { higher for patients with } \\
\text { positive viral isolation than } \\
\text { for those without } \\
\text { isolation. }\left(1.7 \times 10^{8}\right. \\
\left.\text { vs } 6.9 \times 10^{3}\right) \text {. }\end{array}$ & $\begin{array}{l}\text { Symptoms did not } \\
\text { differ between childre } \\
\text { from whom a positive } \\
\text { viral isolation was } \\
\text { obtained vs not. }\end{array}$ \\
\hline $\begin{array}{l}\text { Liu et al. (20) } \\
\text { The Journal of } \\
\text { Infection } \\
\text { (April 18, } \\
2020 \text { ) }\end{array}$ & Taiwan & $\begin{array}{l}\text { Case } \\
\text { report }\end{array}$ & $\begin{array}{l}50 \text { year old } \\
\text { hospitalized woman } \\
\text { with mild disease and } \\
\text { no comorbidities }\end{array}$ & 1 & $\begin{array}{l}\text { Throat and } \\
\text { sputum } \\
\text { samples, } \\
\text { collected } \\
\text { daily. }\end{array}$ & 63 days & 18 days & $\begin{array}{l}\text { Viral cultures positive after } \\
\text { resolution of symptoms. } \\
\text { Antibodies detected on } \\
\text { day } 10 \text {, but viral cultures } \\
\text { remained positive until } \\
\text { day } 18 . \\
\text { Virus isolated from throat } \\
\text { swabs at admission, and } \\
\text { from sputum until } 18 \text { days } \\
\text { after symptom onset. }\end{array}$ & $\begin{array}{l}\text { Fever resolved on day } \\
10 .\end{array}$ \\
\hline $\begin{array}{l}\text { Million et al. } \\
(14) \\
\text { Travel }\end{array}$ & France & $\begin{array}{l}\text { Case } \\
\text { series }\end{array}$ & $\begin{array}{l}\text { Hospitalized patients } \\
\text { with a mean age of } \\
47.9 \text { (SD } 17.5 \text { ), } 2.6 \% \\
\text { had cancer, } 7.4 \% \text { had }\end{array}$ & $\begin{array}{l}1061 \\
\text { (915 } \\
\text { attempt } \\
\text { ed, } 204\end{array}$ & $\begin{array}{l}\text { NP samples, } \\
\text { collected } \\
\text { daily for } 11 \\
\text { participants. }\end{array}$ & $\begin{array}{l}>15 \text { days } \\
\text { (patient } \\
\text { still } \\
\text { testing }\end{array}$ & 9 days & $\begin{array}{l}\text { Prolonged viral shedding } \\
\text { associated with high viral } \\
\text { load at diagnosis, but no } \\
\text { positive viral cultures after }\end{array}$ & Not described. \\
\hline
\end{tabular}




\begin{tabular}{|c|c|c|c|c|c|c|c|c|c|}
\hline $\begin{array}{l}\text { Medicine \& } \\
\text { Infectious } \\
\text { Disease (May, } \\
\text { 2020) }\end{array}$ & & & $\begin{array}{l}\text { diabetes, } 4.3 \% \text { had } \\
\text { coronary artery } \\
\text { disease, } 14 \% \text { had } \\
\text { hypertension, } 10.5 \% \\
\text { had chronic } \\
\text { respiratory disease } \\
\text { and } 5.8 \% \text { had obesity. } \\
973 \text { patients ( } 91.7 \% \\
\text { had good clinical } \\
\text { outcome) with } 38 \\
\text { severe outcomes } \\
\text { including death. }\end{array}$ & $\begin{array}{l}\text { positive } \\
\text { viral } \\
\text { isolation } \\
\text { s, } 11 \\
\text { individu } \\
\text { als with } \\
\text { daily } \\
\text { samples) }\end{array}$ & & $\begin{array}{l}\text { positive at } \\
\text { study end) }\end{array}$ & & day 9. & \\
\hline $\begin{array}{l}\text { van Kampen } \\
\text { et al. (21) } \\
\text { MedrXiv *Pre- } \\
\text { print (June 9, } \\
\text { 2020) }\end{array}$ & $\begin{array}{l}\text { The } \\
\text { Netherla } \\
\text { nds }\end{array}$ & $\begin{array}{l}\text { Case } \\
\text { series }\end{array}$ & $\begin{array}{l}\text { Hospitalized patients } \\
\text { with severe or critical } \\
\text { COVID-19, admitted to } \\
\text { medium acute care } \\
(40,31 \%) \text { or to } \\
\text { intensive care ( } 89, \\
69 \%) .11 \text { patients } \\
\text { were severely } \\
\text { immunocompromised } \\
\text { and } 19 \text { were non- } \\
\text { severely } \\
\text { immunocompromised. }\end{array}$ & $\begin{array}{l}129 \text { ( } 23 \\
\text { individu } \\
\text { als with } \\
\text { positive } \\
\text { viral } \\
\text { isolation } \\
\text { s) }\end{array}$ & $\begin{array}{l}\text { Upper } \\
\text { respiratory } \\
\text { and sputum } \\
\text { samples, } \\
\text { collected } \\
\text { serially from } \\
\text { diagnostic } \\
\text { samples only, } \\
\text { not at pre- } \\
\text { defined } \\
\text { intervals. }\end{array}$ & $\mathrm{N} / \mathrm{A}$ & 20 days & $\begin{array}{l}\text { Median duration of } \\
\text { infectious virus shedding } \\
\text { was } 8 \text { days (IQR } 5-11 \text { ). } \\
\leq 5 \% \text { probability of } \\
\text { isolating infectious virus } \\
\text { when duration of } \\
\text { symptoms was } 15.3 \text { days } \\
\text { or more ( } 95 \% \text { Cl 13.2-17.2) } \\
\text { <5\% probability of } \\
\text { isolation when viral load } \\
\text { went below } 6.51 \text { log10 } \\
\text { RNA copies per mL. } \\
\text { Viral load was associated } \\
\text { with infectious viral } \\
\text { shedding; median viral } \\
\text { load was significantly } \\
\text { higher in culture positive } \\
\text { samples than in culture } \\
\text { negative samples. } \\
\text { Shedding of infectious } \\
\text { virus dropped rapidly to } \\
\text { undetectable levels upon } \\
\text { seroconversion. }\end{array}$ & $\begin{array}{l}\text { Assumption that all } \\
\text { patients with positive } \\
\text { viral isolation were } \\
\text { symptomatic at the } \\
\text { time of sampling, give } \\
\text { the patient population }\end{array}$ \\
\hline
\end{tabular}




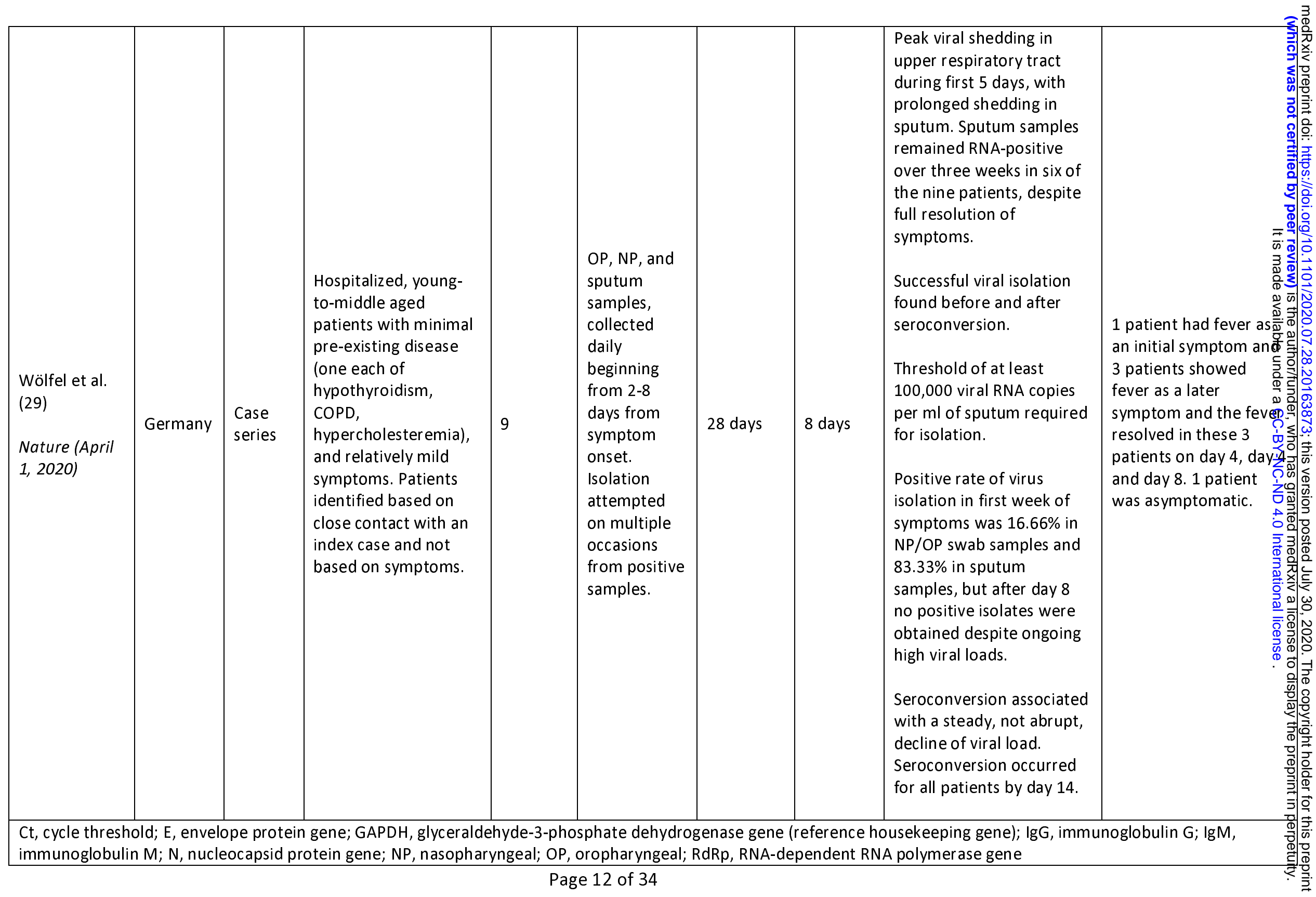


Page 13 of 34

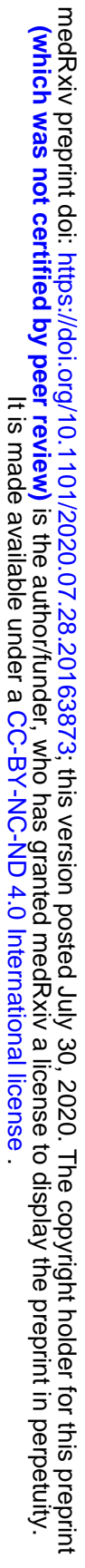




\section{FIGURES}

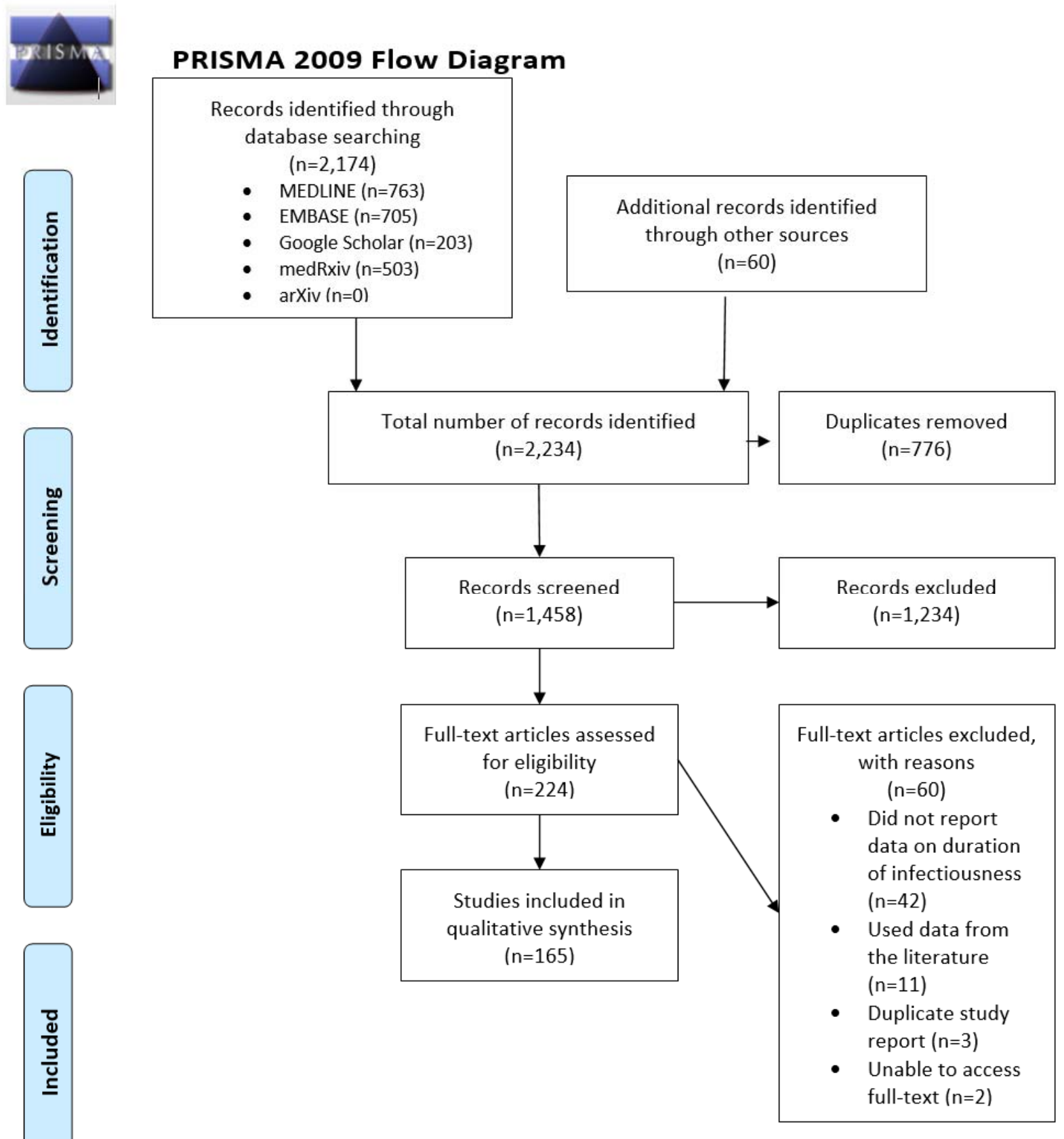

Figure 1. PRISMA flowchart diagram of included studies. The PRISMA flowchart details the number of studies identified through our search, and then included for analysis after screening for eligibility. 


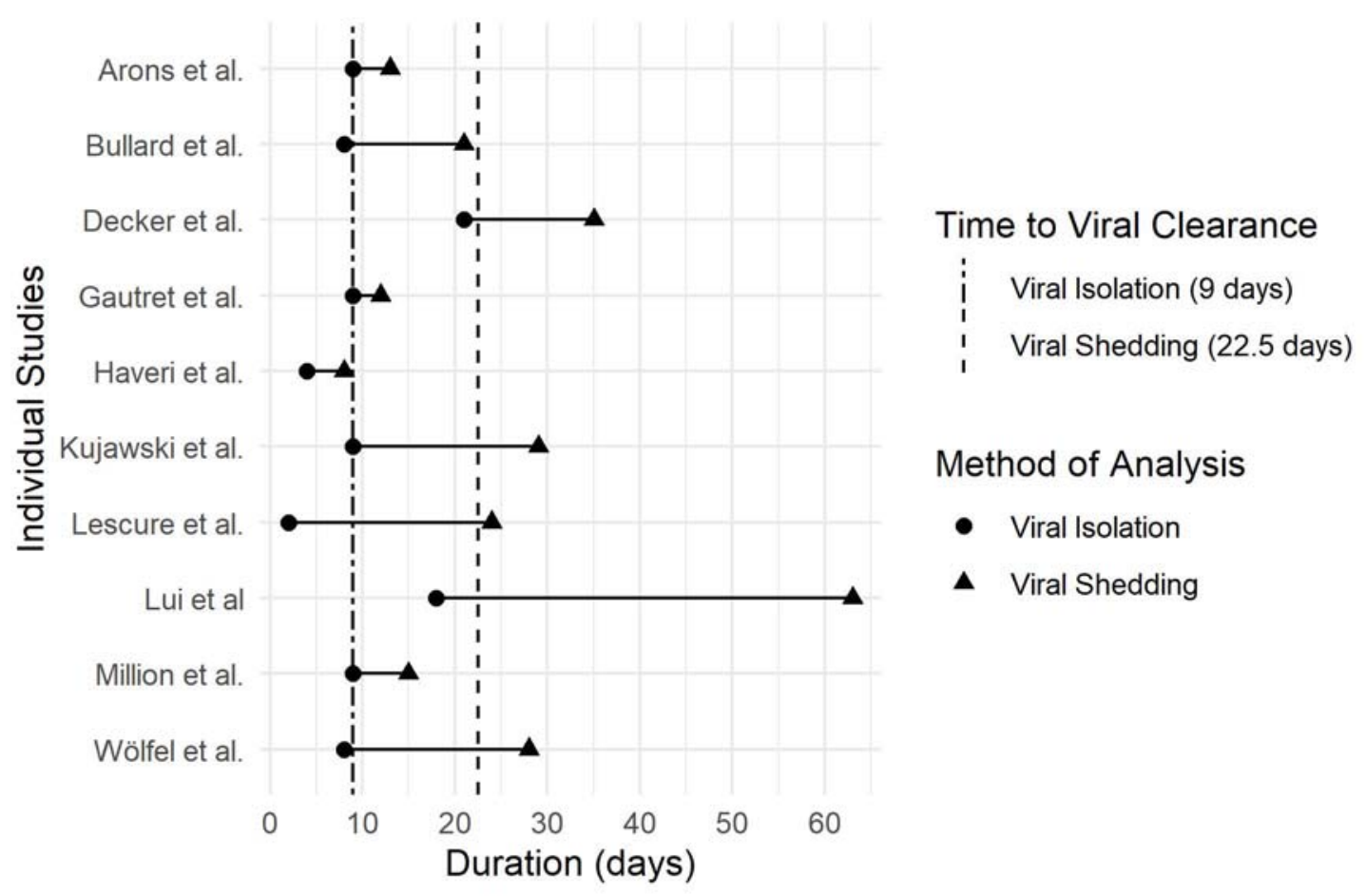

Figure 2. Maximum reported durations of communicability from studies $(n=10)$ with data on viral isolation and viral shedding in respiratory SARS-CoV-2 samples. Each horizontal line represents data from the same study, with points indicating the longest time to viral clearance reported from each study for viral isolation (circles) and viral shedding (triangles). Vertical lines represent median reported values across all studies on longest time to viral clearance for viral isolation (dashed and dotted line) and viral shedding (dashed line).

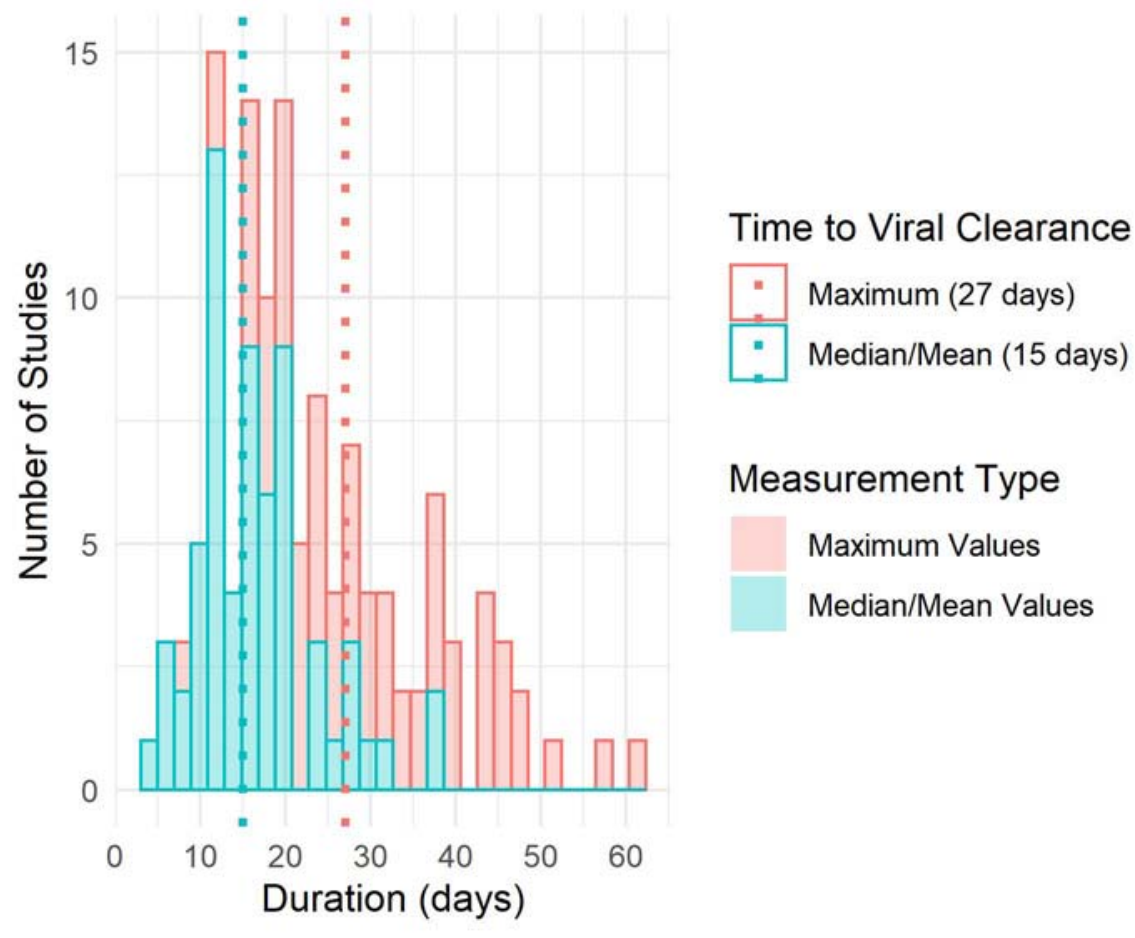

Page 2 of 34 
medRxiv preprint doi: https://doi.org/10.1101/2020.07.28.20163873; this version posted July 30, 2020. The copyright holder for this preprint (which was not certified by peer review) is the author/funder, who has granted medRxiv a license to display the preprint in perpetuity. It is made available under a CC-BY-NC-ND 4.0 International license.

Figure 3. Histograms displaying the distribution of durations of communicability from studies reporting data on both median/mean and maximum durations to viral clearance $(n=63)$. Data on median/mean values are shown in teal and maximum values are shown in pink. Dotted vertical lines refer to median values across all studies for median/mean duration (teal) and maximum duration (pink) until viral clearance. 
medRxiv preprint doi: https://doi.org/10.1101/2020.07.28.20163873; this version posted July 30, 2020. The copyright holder for this preprint (which was not certified by peer review) is the author/funder, who has granted medRxiv a license to display the preprint in perpetuity. It is made available under a CC-BY-NC-ND 4.0 International license .

\section{SUPPLEMENTARY MATERIALS}

\section{Appendix A - Search Terms Used:}

\section{Viral Clearance/Shedding Searches}

\section{MEDLINE}

1. ((()exp Coronavirus/ or exp Coronavirus Infections/ or (coronavirus* or corona virus* or OC43 or

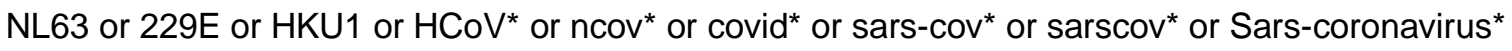
or Severe Acute Respiratory Syndrome Coronavirus $\left.{ }^{\star}\right)$.mp.) and $\left(\left(20191^{*}\right.\right.$ or $\left.202^{*}\right)$.dp. or 20190101:20301231.(ep).)) not (SARS or SARS-CoV or MERS or MERS-CoV or Middle East respiratory syndrome or camel ${ }^{*}$ or dromedar ${ }^{*}$ or equine or coronary or coronal or covidence ${ }^{*}$ or covidien or influenza virus or HIV or bovine or calves or TGEV or feline or porcine or BCoV or PED or PEDV or PDCoV or FIPV or FCoV or SADS-CoV or canine or CCov or zoonotic or avian influenza or H1N1 or H5N1 or H5N6 or IBV or murine corona*).mp.) or ((((pneumonia or covid* or coronavirus* or corona virus* or ncov* or 2019-ncov or sars*).mp. or exp pneumonia/) and Wuhan.mp.) or (2019-ncov or ncov19 or ncov-19 or 2019-novel CoV or sars-cov2 or sars-cov-2 or sarscov2 or sarscov-2 or Sars-coronavirus2 or Sars-coronavirus-2 or SARS-like coronavirus* or coronavirus-19 or covid19 or covid-19 or covid 2019 or ((novel or new or nouveau) adj2 (CoV on nCoV or covid or coronavirus* or corona virus or Pandemi²)) or ((covid or covid19 or covid19) and pandemic*2) or (coronavirus* and pneumonia)).mp. or COVID-19.rx,px,ox. or severe acute respiratory syndrome coronavirus 2.os. or ("32240632" or "32236488" or "32268021" or "32267941" or "32169616" or "32267649" or "32267499" or "32267344" or "32248853" or "32246156" or "32243118" or "32240583" or "32237674" or "32234725" or "32173381" or "32227595" or "32185863" or "32221979" or "32213260" or "32205350" or "32202721" or "32197097" or "32196032" or "32188729" or "32176889" or "32088947" or "32277065" or "32273472" or "32273444" or "32145185" or "31917786" or "32267384" or "32265186" or "32253187" or "32265567" or "32231286" or "32105468" or "32179788" or "32152361" or "32152148" or "32140676" or "32053580" or "32029604" or "32127714" or "32047315" or "32020111" or "32267950" or "32249952" or "32172715").ui.)) and 20191201:20301231.(dt). (8287)

2. (infectious or transmission or transmitted).ti. (130621)

3. ((viral ${ }^{*}$ or virus) adj2 (shed ${ }^{*}$ or clear $^{*}$ or load or dynamics or detect ${ }^{*}$ or assessment or duration)).tw,kf. (54897)

4. ((discharge? or recovered) adj6 positive).tw,kf. (2484)

5. ((communicable or infectious) adj2 period).tw,kf. (496)

6. or/2-5 (185826)

7. 1 and $6(423)$

8. limit 7 to english language (409)

\section{Embase}

1. ((exp Coronavirinae/ or coronavirus ${ }^{*}$.mp.) and (wuhan or beijing or shanghai or 2019-nCoV or Covid-19 or SARS-CoV-2).mp.) or ((Coronavirus*.ti. or (novel coronavirus*.mp. and (exp China/ or china.mp.)) or ((pneumonia.mp. or exp pneumonia/) and Wuhan.mp.) or ("Covid-19" or "2019nCoV" or "SARS-CoV-2").mp. or exp Coronavirus Infection/) and ("2020" or "2021").yr.) (7113)

2. (infectious or transmission or transmitted).ti. (131541) 
medRxiv preprint doi: https://doi.org/10.1101/2020.07.28.20163873; this version posted July 30, 2020. The copyright holder for this preprint (which was not certified by peer review) is the author/funder, who has granted medRxiv a license to display the preprint in perpetuity.

It is made available under a CC-BY-NC-ND 4.0 International license .

3. ((viral ${ }^{\star}$ or virus) adj2 (shed ${ }^{*}$ or clear* or load or dynamics or detect ${ }^{\star}$ or assessment or duration)).tw,kw. (76591)

4. ((discharge? or recovered) adj6 positive).tw,kw. (3547)

5. ((communicable or infectious) adj2 period).tw,kw. (572)

6. or/2-5 (208949)

7. 1 and $6(411)$

8. limit 7 to english language (388)

\section{Google Scholar}

- Covid AND "viral shedding"

- Covid AND "viral clearance"

- Covid AND transmission

- Covid AND asymptomatic

- Covid AND infectious period

\section{medRxiv/arXiv}

- Covid viral shedding

- Covid infectious period

- Covid asymptomatic

- Covid "viral clearance"

\section{Viral Isolation/Culture Searches}

\section{MEDLINE}

Database: Ovid MEDLINE(R) and Epub Ahead of Print, In-Process \& Other Non-Indexed Citations, Daily and Versions $(R)<1946$ to July $01,2020>$

Search Strategy:

$1 \quad((($ exp Coronavirus/ or exp Coronavirus Infections/ or (coronavirus* or corona virus* or OC43 or NL63 or 229E or HKU1 or $\mathrm{HCoV}^{*}$ or ncov* or covid* or sars-cov* or sarscov* or Sars-coronavirus* or Severe Acute Respiratory Syndrome Coronavirus* $)$.mp.) and $\left(\left(20191^{\star}\right.\right.$ or $\left.202^{\star}\right)$.dp. or 20190101:20301231.(ep).)) not (SARS or SARS-CoV or MERS or MERS-CoV or Middle East respiratory syndrome or camel ${ }^{*}$ or dromedar* or equine or coronary or coronal or covidence* or covidien or influenza virus or HIV or bovine or calves or TGEV or feline or porcine or BCoV or PED or PEDV or PDCoV or FIPV or FCoV or SADS-CoV or canine or CCov or zoonotic or avian influenza or H1N1 or H5N1 or H5N6 or IBV or murine corona $\left.{ }^{\star}\right)$.mp.) or ((((pneumonia or covid* or coronavirus* or corona virus* or ncov* or 2019ncov or sars $\left.{ }^{\star}\right)$.mp. or exp pneumonia/) and Wuhan.mp.) or (2019-ncov or ncov19 or ncov-19 or 2019novel CoV or sars-cov2 or sars-cov-2 or sarscov2 or sarscov-2 or Sars-coronavirus2 or Sars-coronavirus2 or SARS-like coronavirus* or coronavirus-19 or covid19 or covid-19 or covid 2019 or ((novel or new or nouveau) adj2 (CoV on nCoV or covid or coronavirus* or corona virus or Pandemi²)) or ((covid or 
medRxiv preprint doi: https://doi.org/10.1101/2020.07.28.20163873; this version posted July 30, 2020. The copyright holder for this preprint (which was not certified by peer review) is the author/funder, who has granted medRxiv a license to display the preprint in perpetuity. It is made available under a CC-BY-NC-ND 4.0 International license .

covid19 or covid-19) and pandemic ${ }^{\star 2}$ ) or (coronavirus* and pneumonia)).mp. or COVID-19.rx,px,ox. or severe acute respiratory syndrome coronavirus 2.os. or ("32240632" or "32236488" or "32268021" or "32267941" or "32169616" or "32267649" or "32267499" or "32267344" or "32248853" or "32246156" or "32243118" or "32240583" or "32237674" or "32234725" or "32173381" or "32227595" or "32185863" or "32221979" or "32213260" or "32205350" or "32202721" or "32197097" or "32196032" or "32188729" or "32176889" or "32088947" or "32277065" or "32273472" or "32273444" or "32145185" or "31917786" or "32267384" or "32265186" or "32253187" or "32265567" or "32231286" or "32105468" or "32179788" or "32152361" or "32152148" or "32140676" or "32053580" or "32029604" or "32127714" or "32047315" or "32020111" or "32267950" or "32249952" or "32172715").ui.)) and 20191201:20301231.(dt). (29800)

2 ((viral ${ }^{\star}$ or virus) adj6 (culture? or isolation or isolated)).tw,kf. (42320)

$3 \quad 1$ and $2(103)$

\section{Embase}

Database: Embase <1974 to 2020 July 01>

Search Strategy:

1 ((exp Coronavirinae/ or coronavirus ${ }^{*} . \mathrm{mp}$.) and (wuhan or beijing or shanghai or 2019-nCoV or Covid-19 or SARS-CoV-2).mp.) or ((Coronavirus*.ti. or (novel coronavirus*.mp. and (exp China/ or china.mp.)) or ((pneumonia.mp. or exp pneumonia/) and Wuhan.mp.) or ("Covid-19" or "2019-nCoV" or "SARS-CoV-2").mp. or exp Coronavirus Infection/) and ("2020" or "2021").yr.) (26353)

2 ((viral ${ }^{*}$ or virus) adj6 (culture? or isolation or isolated)).tw,kw. (41653)

$3 \quad 1$ and $2(106)$

\section{Google Scholar}

- Covid virus isolation

- Covid viral isolation

- Covid virus culture

- Covid viral culture

\section{medRxiv/arXiv}

- Title "COVID" (match all words) and abstract or title "viral isolation" (match phrase words)

- Title "COVID" (match all words) and abstract or title "virus isolation" (match phrase words)

- Title "COVID" (match all words) and abstract or title "virus culture" (match phrase words)

- Title "COVID" (match all words) and abstract or title "viral culture" (match phrase words) 
medRxiv preprint doi: https://doi.org/10.1101/2020.07.28.20163873; this version posted July 30, 2020. The copyright holder for this preprint (which was not certified by peer review) is the author/funder, who has granted medRxiv a license to display the preprint in perpetuity.

It is made available under a CC-BY-NC-ND 4.0 International license .

\section{Appendix B - Inclusion/Exclusion Criteria:}

\begin{tabular}{|c|c|}
\hline Inclusion Criteria & Exclusion Criteria \\
\hline Study had to present empirical data & $\begin{array}{l}\text { Commentaries and editorials were excluded. } \\
\text { Reviews and guidelines were excluded and used } \\
\text { for targeted citation chaining. }\end{array}$ \\
\hline Study was conducted in human populations & In vitro studies excluded \\
\hline $\begin{array}{l}\text { Study had to report on duration of transmission } \\
\text { or possible infectivity }\end{array}$ & $\begin{array}{l}\text { Studies presenting no information on durations } \\
\text { (ie, those on viral kinetics with no durations } \\
\text { reported, or on possibility of vertical transmission } \\
\text { etc) were excluded. } \\
\text { Studies reporting on seroconversion were } \\
\text { excluded. }\end{array}$ \\
\hline
\end{tabular}

\section{SUPPLEMENTARY FIGURES}

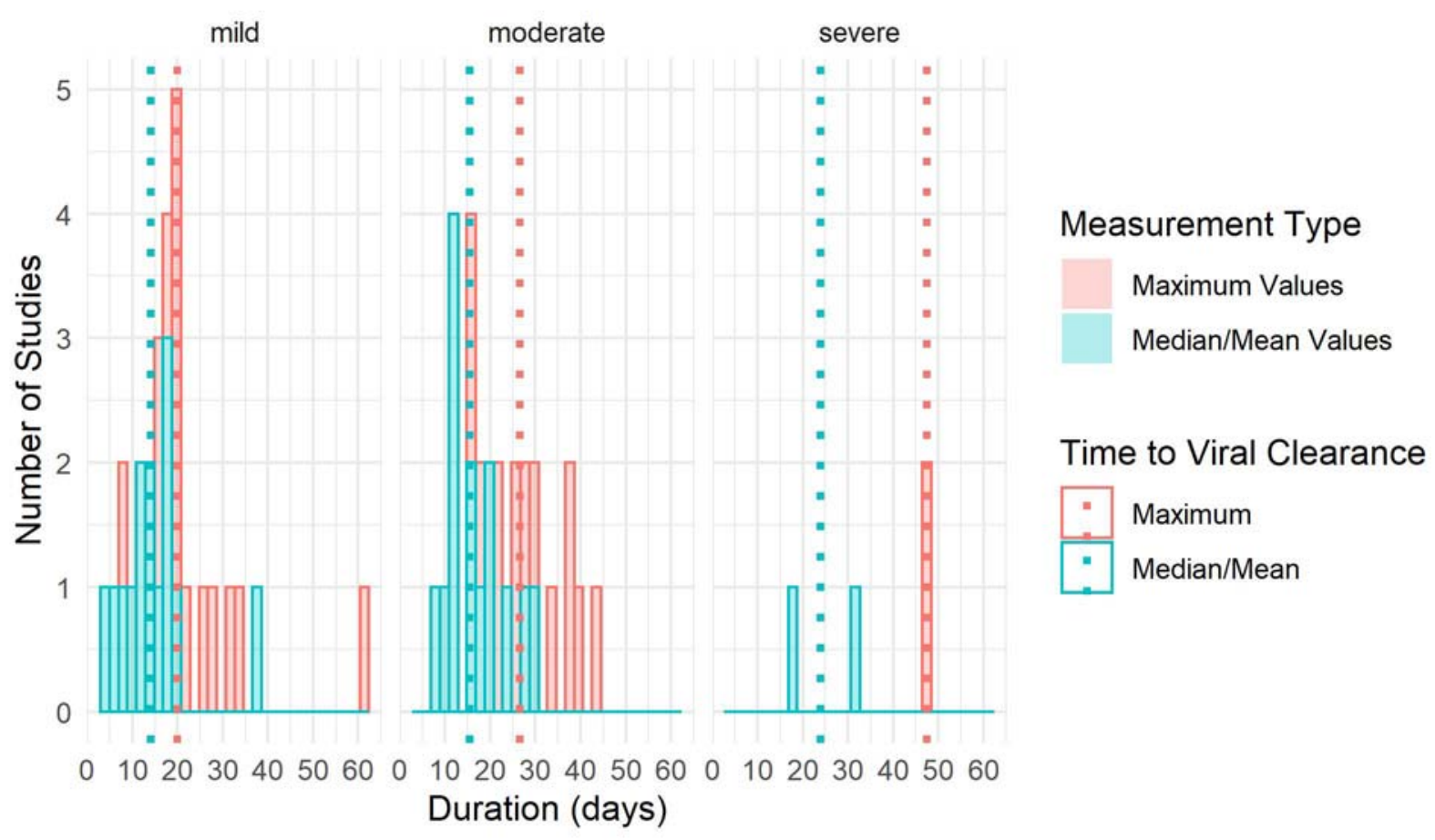

Supplementary Figure 1. Histograms displaying the distribution of durations of communicability from studies reporting data on both median/mean and maximum durations to viral clearance, by disease severity $(\mathbf{n}=\mathbf{3 0})$. Data on median/mean values are shown in teal and maximum values are shown in pink. 
medRxiv preprint doi: https://doi.org/10.1101/2020.07.28.20163873; this version posted July 30, 2020. The copyright holder for this preprint (which was not certified by peer review) is the author/funder, who has granted medRxiv a license to display the preprint in perpetuity.

It is made available under a CC-BY-NC-ND 4.0 International license.

Dotted vertical lines represent median values across studies for median/mean duration (teal) and maximum duration (pink) to viral clearance.

Page 8 of 34 